\title{
DEMOCRACIA DELIBERATIVA E ORÇAMENTO PÚBLICO: EXPERIÊNCIAS DE PARTICIPAÇÃO EM PORTO ALEGRE, BELO HORIZONTE, RECIFE E CURITIBA
}

\author{
Rodrigo Rossi Horochovski
}

\author{
Augusto Junior Clemente
}

\begin{abstract}
RESUMO
O artigo compara instituições participativas orçamentárias de quatro cidades brasileiras: Porto Alegre, Belo Horizonte, Recife e Curitiba. As três primeiras contam com orçamentos participativos e, a última, com audiências públicas para apresentação de propostas à Lei de Diretrizes Orçamentárias $(L D O)$ e à Lei Orçamentária Anual (LOA). O objetivo é analisar em que medida as instituições investigadas têm maior ou menor proximidade com os pressupostos normativos da teoria da democracia deliberativa, pelos quais a legitimidade dos processos e decisões políticas resulta de deliberações públicas, livres e com igualdade de condições de participação dos concernidos. Na pesquisa empírica, consideramos as seguintes dimensões de variáveis: (i) desenho institucional: arcabouço institucional e funcionamento, condições de participação, discussão e deliberação; (ii) contexto: grau de associativismo civil de cada cidade e conformação dos grupos políticos que implantaram os esquemas participativos; (iii) política: alcance da representação e participação social e (iv) accountability: transparência e responsividade potencializadas por esses espaços públicos, diante da sociedade civil. Entre os principais achados, constatamos que a proximidade dos pressupostos da democracia deliberativa é maior nas experiências construídas a partir das bases da sociedade civil e implantadas por grupos políticos com objetivo declarado de aumentar a participação social na deliberação pública. A prevalência de uma burocracia técnica na condução do processo participativo age em sentido oposto.
\end{abstract}

PALAVRAS-CHAVE: democracia; deliberação; orçamento participativo; audiência pública.

\section{INTRODUÇÃO ${ }^{1}$}

Nas décadas após o regime autoritário de 19641985, o Brasil vivenciou a reconstrução de suas instituições políticas representativas e um crescimento inédito das possibilidades de participação política de seus cidadãos, elementos que consubstanciam a gradativa consolidação democrática do país, malgrado suas ambigüidades, contradições, avanços e recuos. Especificamente no tocante à participação, vêm-se produzindo,

1 Este texto é resultado da consolidação de pesquisas iniciais que foram apresentadas em três eventos: IV Congresso Latino Americano de Opinião Pública da WAPOR (World Association for Public Opinion Research), III Seminário Nacional de Sociologia e Política da Universidade Federal do Paraná (UFPR) e IV Seminário Nacional de Ciência Política da Universidade Federal do Rio Grande do Sul (Ufrgs). Agradecemos, primeiramente, as críticas e sugestões dos pareceristas anônimos da Revista de Sociolo- desde a abertura política, expressões associativas que acarretam pressões para o aumento da inclusão da sociedade civil, seus movimentos e organizações, no âmbito da sociedade política (BOSCHI, 1987; DOIMO, 1995; GOHN, 2004). Com isso, ao menos em seu arcabouço normativoinstitucional, o Estado brasileiro absorve a participação social como um elemento constitutivo dos processos decisórios relacionados às políticas públicas (JACOBI, 1996). A formação de arranjos participativos diversos e com maior ou menor grau

gia e Política e aos debatedores dos eventos acima referidos: Leonardo Avritzer, Cláudia Feres Faria, Maria Tarcisa Silva Bega, Luiz Belmiro Teixeira, Cesar Beras e Ligia Mori Madeira. Agradecemos também as leituras e comentários do grupo de pesquisa Processos Participativos na Gestão Pública, liderado por Alfredo Alejandro Gugliano. Por fim, somos gratos às interlocuções oferecidas por Ícaro Engler e Rodrigo Mayer. 
de normatividade legal - fóruns e redes, conselhos gestores, orçamentos participativos, audiências públicas etc. - exprime essa tendência (SCHERERWARREN, 1996; AVRITZER, 2002a).

Uma característica importante dos arranjos em apreço é sua constituição temporal em "ondas participativas", para utilizar a expressão de Faria (2006), com que se criam e incrementam estruturas de oportunidade política abertas a segmentos cada vez mais amplos da população. Emum rápido inventário, visualizamos, na segunda metade dos anos 1970, movimentos, organizações e fóruns relacionados à redemocratização, mas também a temas do cotidiano (meio ambiente, custo de vida e direitos sociais como moradia, saúde e trabalho), identitários e ligados ao novo sindicalismo (SADER, 1995). Ultrapassando as pautas das organizações mobilizadas em torno da centralidade da luta de classes, sobretudo sindicatos e partidos da esquerda tradicional, ganham força ações coletivas em torno de temas como o feminismo, questões étnicas e relacionadas à sexualidade. Tratava-se, na maioria, de iniciativas informais, de resistência e organização possível em face do autoritarismo vigente.

Nos anos 1980, com a abertura política, o Estado brasileiro é premido pelos movimentos retro aduzidos a incorporar, em suas estruturas, a participação da sociedade para além dos procedimentos representativos. As vitórias de coalizões de esquerda em eleições municipais na segunda metade da década ocasionam a construção de uma nova instituição, que, por suas vastas implicações, torna-se objeto privilegiado de análise: o orçamento participativo (OP), que iria difundir-se nas décadas seguintes, sobretudo onde o Partido dos Trabalhadores (PT) conquistou o poder Executivo. Inúmeros estudos apresentam balanços históricos desse processo, podendo-se mencionar alguns dos mais significativos, como os de Navarro (1999), Nylen (2000), Souza (2001), Avritzer (2002b), Wampler (2004), entre outros.

Pedra angular da institucionalização da participação no Brasil, a Constituição Federal de 1988 resultou das mencionadas pressões da sociedade civil. Podemos asseverá-lo na medida em que a carta impõe, em diversos de seus dispositivos, constrangimentos a que todos os entes da federação brasileira promovam a participação da população na elaboração, discussão e deliberação das políticas públicas. Trata-se de um sistema legal híbrido, que combina elementos de representação e participação democráticas (AVRITZER, 2006). Um resultado visível é a multiplicação de conferências e conselhos gestores de políticas públicas com a presença obrigatória da sociedade civil e suas organizações.

Para os propósitos deste artigo, a conseqüência mais significativa é a onda de Audiências Públicas (APs) dos últimos anos, em especial com a regulamentação da carta magna em dispositivos como a Lei Federal n. 10 257/2001 - o Estatuto da Cidade, e a Lei Complementar n. 101 - a Lei de Responsabilidade Fiscal (LRF).

No Estatuto da Cidade, há um capítulo específico à democratização dos municípios, o $5^{\circ}$, que estabelece a obrigatoriedade, nos artigos $43 \mathrm{e}$ 44, de "debates, audiências e consultas públicas" no que diz respeito à gestão orçamentária municipal, em todo o seu ciclo (Plano Plurianual (PPA), Lei de Diretrizes Orçamentárias (LDO) e Lei Orçamentária Anual (LOA)), "como condição obrigatória para sua aprovação pela Câmara Municipal". ALRF trata da transparência na gestão fiscal na Administração Pública. Segundo o Artigo 48, a transparência também deve ser assegurada "mediante incentivo à participação popular e realização de audiências públicas durante o processo de elaboração e de discussão dos planos, Lei de Diretrizes Orçamentárias e orçamentos".

As APs converteram-se, portanto, em mecanismos obrigatórios de gestão pública e apresentam-se como um arranjo institucional que se pretende participativo, sendo aplicadas a matérias as mais diversas, como as de impacto socioambiental e as relacionadas a questões orçamentárias. Essa última modalidade, especificamente com as Audiências Públicas organizadas pela Prefeitura Municipal de Curitiba, compõe o objeto desta investigação, juntamente com os OPs de Porto Alegre, Belo Horizonte e Recife. Nosso objetivo é comparar esses quatro esquemas participativos analisando em que medida eles aproximam-se ou distanciam-se das prescrições da democracia deliberativa. Em especial, procuramos aquilatar em que medida as experiências investigadas oferecem oportunidades para a participação social, como defende essa perspectiva teórica. (Esquadrinhar o conteúdo e, vale dizer, a qualidade da participação em si dos sujeitos foge ao escopo da investigação.) 
Perpassa nossas análises a avaliação das congruências e divergências entre as APs curitibanas e os OPs investigados mediante a operacionalização dos conceitos dessa vertente teórica a partir das dimensões de variáveis propostas por Faria e Ribeiro (2010): (i) desenho institucional: arcabouço e funcionamento, condições de participação, discussão e deliberação; (ii) contexto: grau de associativismo civil de cada cidade e conformação dos grupos políticos que implantaram esses esquemas participativos; (iii) política: alcance da representação e participação social; (iv) accountability: transparência e responsividade potencializadas por esses espaços públicos à Sociedade Civil².

Escolhemos as quatro cidades por serem elas emblemáticas, para operadores e analistas políticos, de modelos de gestão municipal que ora aproximam-se, ora afastam-se. No decorrer do texto, aprofundamos algumas de suas características. Para o momento, cabe mencionar o aspecto principal de cada uma delas relacionado à discussão em curso.

Porto alegre representa a cidade na qual a sua população já foi considerada como dotada de cultura política participativa, realidade que se exprimiria nas múltiplas possibilidades de participação democrática de que o OP é a insígnia maior (AVRITZER, 2002b). Belo Horizonte já recebeu o epíteto de cidade planejada, mas teve um momento de inflexão nos anos 1970 e 1980, decorrente dos problemas de urbanização acelerada (PIRES, 2009). Recife, à semelhança de Porto Alegre, destaca-se na região Nordeste do país pelo forte movimento associativo dos anos 1970, culminando com o Programa Prefeitura nos Bairros (PPB), que mais tarde deu origem ao OP na capital pernambucana (SILVA, 2003). Curitiba é tida como exemplo bem-sucedido de planejamento técnico-burocrático de viés autoritário, em que praticamente todo processo decisório ao longo de sua história seguiu fluxos top-down (SOUZA, 1999).

Este artigo registra os resultados da pesquisa.

2 Fizemos alterações e acréscimos em relação à proposta das autoras, inicialmente voltada à análise dos Conselhos Gestores municipais. Eventuais insuficiências e imprecisões na aplicação das dimensões são de nossa inteira responsabilidade.
Para sua consecução, realizamos consultas a bibliografia e a documentos (sobretudo nos casos de Porto Alegre, Belo Horizonte e Recife), aliadas a observação etnográfica e entrevistas informais, em Curitiba. As seções a seguir trazem uma breve revisão teórica, uma descrição mais detida dos procedimentos de pesquisa e os achados decorrentes de sua aplicação.

\section{DEMOCRACIA DELIBERATIVA}

Em seu desenvolvimento, o debate teórico da democracia constitui uma robusta vertente normativa em cujo interior destacam-se as teorias participativa e deliberativa ${ }^{3}$, sendo que esta última fornece nosso parti pris conceitual. Uma das principais formuladoras da democracia deliberativa sintetiza o argumento central dessa teoria nos seguintes termos: "a legitimidade nas sociedades democráticas complexas precisa ser entendida como o resultado da deliberação pública livre e isenta de constrangimentos a respeito de tudo aquilo que se relaciona a questões de interesse comum" (BENHABIB, 2009, p. 110).

A formação da democracia deliberativa como campo teórico remonta à elaboração da teoria do agir comunicativo, por Jürgen Habermas, na virada para os anos 1960. Naquele momento, o autor em pauta reconstrói o processo de formação e modificação da esfera pública burguesa. Esta constituiu, inicialmente, um espaço razoavelmente livre onde os participantes, por meio da convivência em espaços informais (salões e cafés, por exemplo), construiriam preferências e produziriam consensos racionais mediante $o$ diálogo igualmente livre. Tal dinâmica teria rebatimento na sociedade política, em especial no parlamento, entendido como locus privilegiado à ação comunicativa e à deliberação (HABERMAS, 2003a; 2003b).

O desenvolvimento das forças produtivas e da organização burocrática no capitalismo acarretou, porém, a reestruturação do mundo da vida, em geral, e da esfera pública, em particular, que passariam a ser colonizados pela razão sistêmica do poder econômico e do poder político, representando, respectivamente, os subsistemas da produção tecnificada e do Estado burocratizado.

\footnotetext{
3 O trabalho de Habermas (1995) pode ser uma leitura útil para o reconhecimento das semelhanças e diferenças entre as duas abordagens.
} 
Sobressai, então, uma lógica coercitiva, de racionalidade cognitivo-instrumental, na qual o poder e seus recursos sobrepõem-se à razão que, por sua vez, teria conduzido o projeto moderno iluminista (HABERMAS, 1976; 2000).

A alternativa seria resgatar a lógica que presidira a esfera pública liberal-burguesa em sua gênese, pela constituição de espaços participativos em que predomine a razão comunicativa, lugares de diálogo, discussão e deliberação onde os participantes teriam equalizadas as diferenças/ assimetrias de poder econômico e político que inibem a participação ampliada nas decisões que lhes concernem. Naquilo que Habermas denomina situação ideal de fala, as decisões resultariam do debate aberto em que prevaleceria o melhor argumento. No que concerne ao arcabouço institucional e ao funcionamento, os próprios procedimentos decisórios seriam objeto de discussão e deliberação. $\mathrm{O}$ autor pressupõe, em suma, a possibilidade de uma arena livre e, de certo modo, com conflitos de valor neutros (HABERMAS, 2003a).

Pensando a sociedade em geral, a constituição de espaços de deliberação pública traria como consequiência o aumento da participação para além dos procedimentos tradicionais da democracia representativa e, ato contínuo, a democratização do espaço público e da sociedade, na medida em que, afirma Habermas, a ação comunicativa permearia a esfera do cotidiano - vale dizer, o mundo da vida. É importante frisar que as prescrições habermasianas não foram primordialmente pensadas para espaços institucionais, mormente os da esfera estatal, o que poderia acarretar o risco de não se transformar os espaços de poder. Em face disso, autores como Cohen e Sabel (1998), com a proposta de "poliarquia diretamente deliberativa", defendem a institucionalização dos processos deliberativos para que eles de fato sejam operacionalizados em decisões políticas relevantes. De todo modo, arenas deliberativas que incorporam as referidas prescrições, ao menos em seu desenho institucional, vêm se multiplicando nas últimas décadas (SANTOS, 2003).

Com a profusão de tais arenas, uma participação mais direta da sociedade civil em processos decisórios relacionados a interesses coletivos aumenta continuamente, mormente no âmbito do Estado. A questão que se coloca é o funcionamento dos arranjos participativos vis-àvis os preceitos normativos estabelecidos pela teoria, o que, no fim das contas, constitui o fulcro desta pesquisa. Nesse sentido, pari passu à consolidação do deliberacionismo como campo teórico, assoma uma série de críticas à sua elaboração original, parte das quais trazemos a lume ${ }^{4}$.

Miguel (2005) considera a concepção habermasiana de uma esfera pública burguesa aberta e livre, inclusive de conflitos sociais e políticos, no mínimo, ingênua. Os salões e cafés, referidos por Habermas, eram franqueados apenas a homens burgueses e fechados a outras classes e às mulheres, tal qual acontecia com o próprio sufrágio, que não era universal, mas censitário. Tal cenário precipita, com efeito, um ambiente de discussão entre sujeitos homogêneos, facilitando a obtenção de consensos devido à homologia de agendas e interesses. O próprio parlamento, que para Habermas é um espaço deliberativo privilegiado, reproduzia (continua a fazê-lo, é claro) a distribuição desigual do poder político e econômico. Carecia, em sua formação, até mesmo do simulacro de representatividade que a democracia de massas e o corporativismo de grupos trariam no século $\mathrm{XX}$.

Em uma perspectiva feminista, Fraser (1992) e Young (2001) argumentam que os pressupostos de validade discursiva calcada na neutralidade e na racionalidade podem encapsular assimetrias profundas e arraigadas de poder político e econômico preexistentes. Conforme alerta esta última autora, os participantes da deliberação não deixam para trás as características sociais, étnicas, econômicas etc. que os posicionam na sociedade. Supor que isso seja possível e que o produto final do processo seja resultante do melhor argumento contém uma armadilha: aspectos tidos como neutros - tais como gestual, tipo e modulação da fala, temperamento, vestuário e saberes - podem reproduzir disposições esperadas do homem

\footnotetext{
4 Não nos preocupamos, aqui, com críticas externas à teoria, que questionam a própria participação mais direta dos sujeitos nos assuntos que lhes concernem como parâmetro de qualidade da democracia. Preferimos, em vez disso, debater perspectivas que apontam os limites da teoria habermasiana em face de seu próprio anelo, qual seja, a constituição de uma esfera pública que conduza a uma participação política mais autônoma, igualitária e substantiva.
} 
branco ocidental. Sujeitos fora desse perfil entram no jogo em desvantagem, o que não se captura com a utilização acrítica dos elementos constitutivos da teoria habermasiana.

A busca por elementos comuns, de concordância entre os participantes, defendida por Habermas, pode esvaziar o processo devido à pouca relevância do que é deliberado ou, ainda, produzir falsos consensos quando, de fato, prevalece uma determinada visão, atendendo a interesses específicos, reproduzindo-se a lógica coercitiva dos subsistemas econômico e político. Em vez desta renhida perseguição do consenso, Young propõe o estabelecimento de princípios que, a seu ver, tornariam a deliberação um processo mais efetivo, um dos quais ela denomina "narrativa". Em sua fórmula original, as normas de deliberação privilegiam o discurso frio, desapaixonado e privilegiam a linguagem "literal" sobre a linguagem figurativa (hipérboles e metáforas, p. ex.). O diálogo requer, no entanto, uma pluralidade de perspectivas e de estilos de discurso. É preciso explicar a possibilidade de comunicação por meio de grandes diferenças de cultura e posição social. Contemplar tais diferenças é o desafio que a incorporação das narrativas dos sujeitos, no processo, visa enfrentar.

Fraser, em direção similar, defende o abandono da noção de esfera pública única concebida por Habermas e a incorporação nos processos deliberativos dos grupos excluídos com suas lógicas e preocupações, e em seus próprios termos, no que a autora denominou contra-públicos subalternos (subaltern counterpublics). Quando não são participantes diretos na formulação das políticas públicas, os contrapúblicos subalternos constituem-se, ao menos, como públicos formadores de opinião, capazes de pressionar quem efetivamente toma as decisões políticas, incrementando, desse modo, a própria democracia representativa. Trata-se, enfim, de conceber a deliberação como um processo aberto a públicos heterogêneos, múltiplos, que nele vejam sentido e relevância e que, por isso mesmo, a ele afluam. Quando se trata de instituições participativas, como as ora analisadas, esse requisito deve estar presente tanto nos elementos constituintes do desenho institucional, quanto nas práticas efetivas que garantem a ocupação do espaço participativo por todos os afetados pelo que se está deliberando.

Para Benhabib (1992; 2009), insuficiências da formulação habermasiana original podem ser superadas pela adoção de um modelo descentralizado de esfera pública. Alicerçado em uma pluralidade de modos de associação, esse modelo comportaria diferentes expressões organizativas, desde as mais informais iniciativas dos cidadãos, incluindo movimentos sociais e de vizinhança, às mais formais, como organizações não-governamentais (ONGs), associações sem fins lucrativos, fóruns, sindicatos, partidos políticos etc. Agindo em rede, imbricando-se, ora confrontando-se ora confluindo, essas expressões associativas propiciariam a ebulição de uma conversação pública, eventualmente anônima, com espaço para argumentação, contestação e deliberação; expressões que podem influenciar tanto as decisões políticas, tornando-as mais transparentes e responsivas, quanto estimular a formação de espaços formais de deliberação. Aparentemente, terá sido esse o caso do orçamento participativo, como se verá adiante.

No cerne de todos esses apontamentos críticos vislumbramos questões referentes ao alcance da deliberação em Habermas - ora insuficiente, quanto à absorção de diferentes grupos e suas narrativas e inputs societais, ora excessivo, quando se leva em conta até que ponto obtém-se o consenso e, no limite, constrói-se o que se poderia considerar o bem comum. Em um comentário específico a esse ponto, Shapiro (2005) aduz a pertinência de pensar-se a realização do bem comum não como realização de uma vontade geral, à Rousseau, mas sim como a situação que satisfaz um interesse coletivo de evitar-se a dominação ou de que as decisões políticas não sejam mero resultado da agregação de preferências, que se poderia depreender da leitura de Maquiavel. Essa parece ser a perspectiva que a teoria deliberativa vem adotando.

Um possível corolário desse debate é o de que a necessidade de adequar os conceitos da teoria às exigências empíricas gera transformações em seu seio. Segundo Faria (2010), a partir de um movimento rumo à busca de evidências empíricas, a teoria deliberativa passou a propor: (i) formas flexíveis de discursos enfatizando mais os resultados do que o processo de deliberação (WARREN, 2002); (ii) outros tipos de atividades que funcionem como influência sob a condição de conflitos de interesses, como a barganha e a negociação, que passam ao largo da forma deliberativa de democracia (MANSBRIDGE, 
1999; 2007; MANSBRIDGE et alii, 2010; MOUFFE, 2005); (iii) meios comunicacionais que vão além do discurso racional - a retórica, a narrativa etc. (YOUNG, 2001) - e (iv) uma concepção pluralista de bem comum. Da mesma forma, só que de maneira contraposta, partindo da premissa de que as práticas democratizantes, quando confrontadas com a lógica sistêmica, não necessariamente precisam sucumbir aos seus imperativos (um dos principais temores de Habermas), outros autores passaram a propor arranjos institucionais intermediários e híbridos, a fim de gerar estabilidade a tais práticas, inaugurando outra fase da agenda de pesquisa sobre participação social, sem afastar-se do arcabouço deliberacionista (COHEN \& ROGERS, 1995; AVRITZER, 1996; 2002a; DRYZEK, 2000; DAGNINO, 2002; FUNG \& WRIGHT, 2003).

Se, por um lado, esse giro na direção do empírico gerou ganhos metodológicos e aplicações em diversos campos - pode-se conferi-los no balanço de Chambers (2009) -, por outro, a forma como ele é sugerido traz conseqüências importantes, pois, a fim de operacionalizar os conceitos deliberativos, a estratégia desses autores é reintroduzir nos seus modelos noções referentes a autointeresse, conflito etc. Esse movimento acaba por ter um duplo sentido: aproxima a teoria deliberativa das abordagens pluralista e neocorporativa e a distancia dos seus conceitos inaugurais: esfera pública e ação comunicativa (FARIA, 2010), podendo-se questionar se essa opção por uma versão supostamente mais realista vai gerar um potencial crítico voltado à própria teoria deliberativa: "a ausência da ideia de esfera pública, central na teoria deliberativa 'clássica' como lócus privilegiado de formação de uma opinião pública reflexiva que envolve mobilização, tematização e interpretações de diferentes temas, perspectivas e interesses, empobrece [...] a proposta supostamente 'realista' de deliberação democrática. Tal esfera, vale lembrar, também faz parte de um sistema maior, caracterizado por diferentes níveis que comportam diferentes tipos de comunicação e ação" (idem, p. 12).

Os elementos acima sugerem aperfeiçoamentos à teoria deliberativa e abrem a possibilidade de modificações e acréscimos que permitam conciliar seus elementos prescritivos e descritivos, notadamente na análise e aplicação de arranjos participativos reais. A democracia deliberativa surgiu com o resgate de uma dimensão pública das questões sociais e políticas por meio do revigoramento dos espaços públicos capazes de definir os rumos da ação governamental e das políticas públicas. A presente pesquisa procura analisar os formatos deliberativos sem perder de vista a abordagem "clássica", principalmente no que diz respeito à conexão dos desenhos institucionais à esfera pública e à ação comunicativa, sem, obviamente, deixar de reconhecer as limitações dessa abordagem e a possibilidade de incorporar elementos que a tornem mais frutífera.

\section{AUDIÊNCIAS PÚBLICAS E ORÇAMEN- TOS PARTICIPATIVOS: CONGRUÊNCIAS EDIVERGÊNCIAS}

Em um continuum entre teoria e prática, ambicionamos estabelecer uma régua, assumidamente normativa, que nos permita aferir o quanto cada uma das experiências de participação investigadas aproxima-se ou afasta-se dos pressupostos da democracia deliberativa, como teorizamo-la acima. A idéia é avaliar e cotejar os OPs e as APs em exame.

Do ponto de vista metodológico, a pesquisa é um estudo comparativo de quatro cidades e suas instituições participativas orçamentárias. Priorizamos o exame de instituições implantadas pelos poderes executivos municipais e que fossem presenciais, permitindo a comunicação face a face entre os participantes. (Portanto, não compõem esta investigação arranjos participativos organizados por outros atores, p. ex., câmaras municipais, ou que operem em ambientes virtuais, a exemplo do OP Digital de Belo Horizonte ou das consultas online patrocinadas pela Prefeitura de Curitiba.)

No caso das cidades com orçamento participativo - Porto Alegre, Belo Horizonte e Recife -, alvo de inúmeras pesquisas, o procedimento consistiu da coleta de dados secundários em material bibliográfico e documentos oficiais das prefeituras municipais e, salvo indicação, os dados citados provêm desta última fonte. Para Curitiba, em face da carência de informação, realizamos uma observação etnográfica das audiências públicas, organizadas pelo poder Executivo, durante o ano de 2010. Algumas entrevistas informais, com participantes das audiências, também foram feitas e nossas afirmações sobre a cidade advêm, praticamente em sua totalidade, desses dois procedimentos ou de documentos oficiais do município. 
As dimensões que orientaram as análises formaram um roteiro (Quadro 1). Compuseram cada uma das dimensões duas ou mais variáveis, cuja mensuração deu-se por meio da constatação, em cada uma das instituições participativas, da presença (fraca ou forte) ou ausência de elementos que, segundo nosso entendimento, são constitutivos da democracia deliberativa. A partir desse roteiro, construímos as inferências que propiciaram nossos diversos achados.

QUADRO 1-ROTEIRO DE ANÁLISE

\begin{tabular}{|c|c|c|c|c|c|}
\hline \multicolumn{4}{|c|}{ Instituição Participativa-Cidade: } & & \\
\hline \multicolumn{6}{|c|}{ DIMENSÃO DESENHO INSTITUCIONAL } \\
\hline \multirow{2}{*}{ Variáveis } & \multirow{2}{*}{$\begin{array}{c}\text { Ausência (0), Presença Fraca (1), } \\
\text { Presença Forte (2) de: }\end{array}$} & \multicolumn{4}{|c|}{ Pontuação } \\
\hline & & 0 & 1 & 2 & ? \\
\hline $\begin{array}{l}\text { Arcabouço institucional e } \\
\text { funcionamento }\end{array}$ & \multicolumn{5}{|l|}{$\begin{array}{l}\text { Formulação das regras pelos } \\
\text { cidadãos }\end{array}$} \\
\hline Condições de participação & \multicolumn{5}{|l|}{$\begin{array}{l}\text { Esferas amplas (para toda a } \\
\text { sociedade) de participação }\end{array}$} \\
\hline Discussão & \multicolumn{5}{|l|}{$\begin{array}{l}\text { Espaços e fluxos de debates e } \\
\text { negociações }\end{array}$} \\
\hline \multirow[t]{2}{*}{ Deliberação } & \multicolumn{5}{|l|}{ Delegação efetiva de poder } \\
\hline & & \multicolumn{3}{|c|}{ Subtotal } & \\
\hline \multicolumn{6}{|c|}{ DIMENSÃO CONTEXTO } \\
\hline \multirow{2}{*}{ Variáveis } & \multirow{2}{*}{$\begin{array}{c}\text { Ausência (0), Presença Fraca (1), } \\
\text { Presença Forte (2) de: }\end{array}$} & \multicolumn{4}{|c|}{ Pontuação } \\
\hline & & 0 & 1 & 2 & $?$ \\
\hline Associativismo & \multirow{2}{*}{\multicolumn{5}{|c|}{$\begin{array}{l}\text { Níveis de associativismo que } \\
\text { sustentem os desenhos } \\
\text { Processos bottom-up na implantação } \\
\text { do desenho }\end{array}$}} \\
\hline \multirow[t]{2}{*}{ Conformação dos grupos políticos } & & & & & \\
\hline & & \multicolumn{3}{|c|}{ Subtotal } & \\
\hline \multicolumn{6}{|c|}{ DIMENSÃO POLÍTICA } \\
\hline \multirow{2}{*}{ Variáveis } & \multirow{2}{*}{$\begin{array}{c}\text { Ausência (0), Presença Fraca (1), } \\
\text { Presença Forte (2) de: }\end{array}$} & \multicolumn{4}{|c|}{ Pontuação } \\
\hline & & 0 & 1 & 2 & $?$ \\
\hline Representação & \multirow{2}{*}{\multicolumn{5}{|c|}{$\begin{array}{l}\text { Públicos múltiplos } \\
\text { Ocupação efetiva do espaço } \\
\text { participativo }\end{array}$}} \\
\hline Participação & & & & & \\
\hline & & \multicolumn{3}{|c|}{ Subtotal } & \\
\hline \multicolumn{6}{|c|}{ DIMENSÃO ACCOUNTABILITY } \\
\hline \multirow{2}{*}{ Variáveis } & \multirow{2}{*}{$\begin{array}{c}\text { Ausência (0), Presença Fraca (1), } \\
\text { Presença Forte (2) de: }\end{array}$} & \multicolumn{4}{|c|}{ Pontuação } \\
\hline & & 0 & 1 & 2 & $?$ \\
\hline Transparência & Prestação de contas & & & & \\
\hline \multirow[t]{3}{*}{ Responsividade } & $\begin{array}{l}\text { Correspondência entre inputs e } \\
\text { outputs }\end{array}$ & & & & \\
\hline & \multicolumn{5}{|c|}{ Subtotal } \\
\hline & INDICE DE DEMOCRACIA DEL & ER & IVA & & \\
\hline
\end{tabular}

FONTE: Os autores. 
O roteiro permitiu quantificar o desempenho das instituições participativas de cada cidade, mediante a atribuição de pontos para os elementos constitutivos da democracia deliberativa, constantes da discussão teórica acima. Quando ausente, a pontuação era nula. Para presença "fraca" atribuímos um ponto e, para presença "forte", dois pontos. Como eram dez as variáveis em exame, construímos um índice, a que denominamos Índice de Democracia Deliberativa (IDD), composto por uma escala de 20 pontos na qual, quanto mais próxima desse número a pontuação atingida, maior a aderência da instituição participativa à democracia deliberativa. Para a exposição dos resultados, discutimos o desempenho das quatro cidades em cada uma das variáveis. As cidades são apresentadas conforme um critério puramente cronológico, na ordem em que elas adotaram o arranjo participativo analisado. Por esse motivo, aliás, a pesquisa apresenta diferentes recortes temporais. Cada uma das experiências participativas foi avaliada desde sua constituição até o presente e conforme os dados disponíveis, razão porque as análises por vezes abrangem períodos distintos, quando não se remetem ao contexto anterior que as engendrou.

\section{III.1. Desenho institucional ${ }^{5}$}

III.1.1. Arcabouço institucional e funcionamento

O Orçamento Participativo de Porto Alegre iniciou-se em 1989, ano da posse do primeiro Prefeito eleito pelo PT, Olívio Dutra, na capital gaúcha. Atualmente, o OP está estruturado em 17 assembléias regionais e seis temáticas (Quadro 2). Até 2008, havia duas rodadas de assembléias em cada uma dessas divisões. A partir de 2009, na gestão de José Fogaça - eleito pelo Partido Popular Socialista (PPS) e depois re-filiado ao Partido do Movimento Democrático Brasileiro (PMDB) -, foi suprimida a segunda rodada de assembléias, com a justificativa de simplificar a dinâmica.

As assembléias são a única instância na qual todo e qualquer cidadão pode tomar decisões de maneira direta, ainda que sua participação seja mediada por algum nível de organização - é

\footnotetext{
5 Salvo indicação, as informações que possibilitaram as análises desta e das demais dimensões foram retiradas de documentos publicados nos sítios das prefeituras municipais, respectivamente: Belo Horizonte $(2007 ; 2011)$, Curitiba (2009; 2011), Porto Alegre (2010) e Recife (2011).
}

necessário o participante relacionar-se a movimento social, associação, comitê de bairro etc. O critério de participação é a moradia, no caso das regionais, e o interesse, no caso das temáticas (AVRITZER, 2002b). Nas assembléias, indicamse as demandas para o orçamento e elegem-se delegados para o Conselho do Orçamento Participativo (COP) e para os fóruns regionais e temáticos, que são, na verdade, instâncias representativas. A discussão do regimento interno (RI) se dá nos fóruns regionais e temáticos, nos meses de novembro e dezembro no ano anterior ao da construção da peça orçamentária. Se por um lado, isso significa que são os cidadãos, por meio de delegados, que constroem as regras de funcionamento do OP, por outro lado, essa participação não é propriamente direta.

Belo Horizonte conta com três modalidades de OP: OP Regional, OP Digital e OP Habitação. Analisamos aqui somente o Regional, o primeiro a ser implantado, em 1993, na gestão de Patrus Ananias (PT). Entre as transformações e "correções" que o seu formato original sofreu, a partir de 1998 o ciclo aumentou de um para dois anos e, em 2003, foi introduzido o critério técnico sobre a determinação das demandas: as Áreas Prioritárias para inclusão urbano-social (PIRES, 2009). A cidade é dividida em nove regiões administrativas (Quadro 2), as quais se dividem em sub-regiões, que correspondem a uma ou mais Unidades de Planejamento (UPs).

Os trabalhos começam nas assembléias de apresentação das diretrizes, metodologia, calendário e recursos financeiros aprovados para cada região. A seguir, grupos de no mínimo dez cidadãos promovem discussões e definem as demandas locais por meio de formulários, os quais recebem pareceres de órgãos da Prefeitura Municipal de Belo Horizonte (PMBH). Se a demanda não for aprovada por razões legais ou técnicas, a comunidade deve preencher outro formulário substituindo a solicitação. Na abertura das assembléias da primeira rodada, o Regimento Interno (RI) é lido, discutido e aprovado em plenária. Ou seja, os participantes determinam as regras do jogo. A segunda rodada compõe-se de reuniões nas sub-regiões para pré-seleção de 25 solicitações (submetidas à avaliação técnica) e eleição dos delegados ao Fórum Regional de Prioridades Orçamentárias, a primeira instância decisória. Findas as assembléias, tem início a Caravana de Prioridades, na qual os delegados 
eleitos visitam os investimentos pré-selecionados - condição para votar no Fórum. Neste, são discutidos os 25 empreendimentos pré-selecionados para a eleição, dos 14 que comporão o Plano Regional de Empreendimentos do Orçamento Participativo. Nesse momento é eleita a Comissão de Acompanhamento, Fiscalização e Execução do Orçamento Participativo (Comforça) - que supervisiona o encaminhamento das obras escolhidas.

O OP de Recife, iniciado na segunda gestão de Jarbas Vasconcelos (1993-1997), atualmente tem um ciclo semelhante ao de seu congênere portoalegrense. Trata-se de um fluxo contínuo, que se inicia em um ano e termina no ano seguinte. Há uma etapa inicial com discussões em pequenos grupos nas vizinhanças, seguidas de plenárias regionais e temáticas (Quadro 2), em duas rodadas, quando, além da indicação de prioridades e demandas ao orçamento, elegem-se delegados para o COP, instância decisória máxima. Em Recife, os novos delegados instalam-se nos fóruns, geralmente realizados no mês de agosto, e na discussão do método, no início do ano, momentos em que, mesmo de maneira representativa, os cidadãos conseguem participar da definição das regras de funcionamento do jogo.

Em Curitiba, as Audiências Públicas Orçamentárias começaram como ferramentas de gestão do poder Executivo municipal com vistas à construção da Lei de Diretrizes Orçamentárias (LDO) e da Lei Orçamentária Anual (LOA) - cf. Art. 165 da Constituição Federal (CF). São disposições legais do Art. 48 da Lei de Responsabilidade Fiscal (LRF), e do Art. 44 da
Lei n. 10 257/2001 - Estatuto da Cidade, que defendem a promoção do debate, a transparência e a publicidade da gestão pública, bem como o incentivo à participação popular na formulação da agenda orçamentária municipal.

As Regionais (Quadro 2) são o locus das reuniões nas APs. O processo compõe-se de duas fases de consultas populares. A primeira, visando à construção da LDO, é cumprida no primeiro semestre de cada ano. Realiza-se uma rodada de APs nas regionais e bairros da cidade e mais uma AP Geral ${ }^{6}$ na qual a Prefeitura Municipal de Curitiba (PMC), por meio da Secretaria Municipal de Planejamento (Seplan), apresenta a LDO à população com sua hierarquia de prioridades, construídas, segundo o poder Executivo municipal, pela própria população por meio das APs. Ao término dessa fase, o poder Executivo municipal envia a LDO para a Câmara Municipal. Votada pelos vereadores, a LDO retorna ao poder Executivo para sanção do prefeito. A segunda fase ocorre no segundo semestre e visa à confecção da LOA. O procedimento é o mesmo, i.e., uma rodada de APs em cada Regional e mais uma AP geral na qual a Seplan apresenta a LOA à população, para em seguida enviá-la para a Câmara dos Vereadores. A forma de participação dá-se por meio de sugestões registradas em fichas de Consulta Popular, que são encaminhadas à Seplan. Note-se que, do ponto de vista formal, trata-se de mera consulta, e, embora não haja um regimento interno que contenha normas de funcionamento, elas são estabelecidas e comunicadas pelo corpo técnico da prefeitura, de modo que os cidadãos também não participam de sua elaboração.

QUADRO 2 - CONFIGURAÇÃO BÁSICA DA PARTICIPAÇÃO SOCIAL NAS CIDADES E INSTITUIÇÕES PESQUISADAS

\begin{tabular}{|c|c|}
\hline \begin{tabular}{|l|} 
CIDADE/ \\
INSTITUICCÃO \\
\end{tabular} & CONFIGURAÇÃO \\
\hline & $\begin{array}{l}\text { - Uma rodada de assembléias em } 17 \text { regionais: Humaitá-Navegantes, Noroeste, Leste, } \\
\text { Lomba do Pinheiro, Norte, Nordeste, Partenon, Restinga, Glória, Cruzeiro, Cristal, } \\
\text { Centro-Sul, Extremo Sul, Eixo Baltazar, Sul, Centro e llhas. Abertas à participação de } \\
\text { todos os cidadãos com relação com organizações e movimentos da sociedade civil, } \\
\text { indicam demandas e elegem delegados ao Fórum do OP e conselheiros ao COP. }\end{array}$ \\
\hline $\begin{array}{l}\text { Porto Alegre/ } \\
\text { OP }\end{array}$ & $\begin{array}{l}\text { - Uma rodada de assembléias temáticas: Circulação, Transporte e Mobilidade Urbana; } \\
\text { Saúde e Assistência Social; Educação, Esporte e Lazer; Cultura; Desenvolvimento } \\
\text { Econômico, Tributação e Turismo; Organização da Cidade e Desenvolvimento Urbano e }\end{array}$ \\
\hline
\end{tabular}

6 "Geral" é o termo dado pelos próprios técnicos da PMC 


\begin{tabular}{|c|c|}
\hline & $\begin{array}{l}\text { Ambiental. Abertas à participação de todos os cidadãos com relação com organizações } \\
\text { e movimentos da sociedade civil, indicam demandas e elegem delegados ao Fórum do } \\
\text { OP e conselheiros ao COP. } \\
\text { - Reuniões do Fórum do Orçamento Participativo e do COP. Apenas delegados e } \\
\text { conselheiros têm poder de deliberação. }\end{array}$ \\
\hline $\begin{array}{l}\text { Belo } \\
\text { Horizonte/ } \\
\text { OP }\end{array}$ & $\begin{array}{l}\text { - Assembléias em nove regiões: Barreiro, Centro-Sul, Leste, Nordeste, Noroeste, Norte, } \\
\text { Oeste, Pampulha e Venda Nova - subdivididas em } 42 \text { sub-regiões e } 80 \text { UPs. Para a } \\
\text { distribuição de recursos do OP são consideradas } 79 \text { UPs, pois a UP UFMG é uma área } \\
\text { exclusiva do campus da Universidade Federal de Minas Gerais. Abertas à participação } \\
\text { de todos os cidadãos, indicam demandas e elegem delegados à Comforça. } \\
\text { - Caravanas das prioridades e Reuniões da Comforça. Apenas delegados têm poder de } \\
\text { deliberação. }\end{array}$ \\
\hline $\begin{array}{l}\text { Recife/ } \\
\text { OP }\end{array}$ & $\begin{array}{l}\text { - Reuniões em pequenos grupos, nas microrregiões para indicação de prioridades e } \\
\text { demandas. } \\
\text { - Duas rodadas de plenárias nas regiōes } 1 \text { a } 6 \text { (cada região é subdividida em três } \\
\text { microrregiões, totalizando } 18 \text {, designadas de } 1.1 \text { a 6.3). Abertas à participação de todos } \\
\text { os cidadãos, indicam demandas e elegem delegados ao Fórum de Delegados e os } \\
\text { conselheiros ao COP. Para participar da segunda rodada, é necessário ter se inscrito } \\
\text { na primeira. } \\
\text { - Duas rodadas de plenárias temáticas: Educação, Saúde, Assistência social, } \\
\text { Desenvolvimento econômico, Desenvolvimento Urbano e Ambiental, Mulher, Cultura. } \\
\text { Abertas à participação de todos os cidadãos, indicam demandas e elegem delegados } \\
\text { ao Fórum de Delegados e os conselheiros ao COP. Para participar da segunda rodada, } \\
\text { é necessário ter se inscrito na primeira. } \\
\text { - Reuniões do Fórum do Orçamento Participativo e no COP. Apenas delegados e } \\
\text { conselheiros têm poder de deliberação. }\end{array}$ \\
\hline $\begin{array}{l}\text { Curitibal } \\
\text { AP }\end{array}$ & $\begin{array}{l}\text { - Uma Audiência Pública para coleta de sugestōes à LDO e uma Audiência Pública para } \\
\text { a coleta de sugestões à LOA, em nove Administraçães Regionais: Matriz, Boqueirão, } \\
\text { Boa Vista, Pinheirinho, Bairro Novo, Portão, Santa Felicidade, CIC (Cidade Industrial de } \\
\text { Curitiba) e Cajuru. Abertas à participação de todos os cidadãos, que indicam áreas } \\
\text { prioritárias para investimento. Não há deliberação. } \\
\text { - Uma Audiência Pública Geral da LDO e uma Audiência Pública Geral da LOA. Abertas } \\
\text { à participação de todos os cidadãos, que indicam áreas prioritárias para investimento. } \\
\text { Não há deliberação. }\end{array}$ \\
\hline
\end{tabular}

FONTE: os autores, a partir de Belo Horizonte (2007; 2011), Curitiba (2009; 2011), Porto Alegre (2010) e Recife (2011).

A análise da variável em exame - "arcabouço institucional e funcionamento", medida pela "formulação das regras pelos cidadãos" - revela que, nas capitais com OPs, tal formulação está presente, com intensidade forte em Belo Horizonte

para designar essa AP de apresentação e sugestões finais da LDO e LOA. (a despeito da forte mediação da $\mathrm{PMBH}$ ) e fraca em Porto Alegre e Recife, na medida em que nestas últimas os procedimentos são decididos em instâncias representativas, por delegados. Em Curitiba, a ausência de regras escritas e a determinação de todos os procedimentos pelos representantes do poder Executivo, fazem com que os cidadãos tenham presença nula na elaboração das regras do jogo. As APs da capital 
paranaense não atendem, portanto, a um requisito fundamental da democracia deliberativa.

\section{III.1.2. Condições de participação}

O OP é um espaço aberto à participação dos cidadãos de Porto Alegre, desde que eles organizem-se em alguma forma de ação coletiva - o que já introduz um limite à participação mais ampla quando se considera a baixa taxa de adesão a organizações associativas, inclusive na capital gaúcha, como se verá adiante. Todo participante das assembléias regionais e temáticas é elegível para compor as demais instâncias, mas somente nessas assembléias a participação é livre e direta, ou seja, os presentes podem participar da discussão e decisão relacionadas a indicar demandas e eleger delegados e conselheiros, para o Fórum do OP e o COP. Para este, por exemplo, cada regional elege dois conselheiros titulares e dois suplentes. É o COP quem, no limite, toma as decisões. Por um lado, isso limita um ciclo mais completo de deliberação com participação social direta. Por outro lado, seus integrantes foram escolhidos entre cidadãos ativos, que necessariamente participaram de instâncias deliberativas mais amplas, do ponto de vista da quantidade de participantes. Nesse sentido, exercem papel mediador, de levar às agendas da arena representativa, os temas - conseqüentemente, demandas - que circulam desde as esferas informais de discussão, passando por reuniões e assembléias mais amplas.

O desenho institucional do OP segue, destarte, o modelo piramidal proposto por Macpherson (1982) para a democratização das instituições representativas mediante o alargamento da participação. A discussão do RI e dos critérios de hierarquização dos recursos são pontos de partida dentro de um ciclo ininterrupto. Por um lado, além do caráter contínuo do fluxo de participação, discussão e decisão, há o fomento ao diálogo entre as instâncias, o que, ao menos formalmente, submete as decisões à sociedade civil, suas organizações e movimentos. Quebra-se, desse modo, o monopólio decisório das instituições tradicionais localizadas na esfera estatal e abre-se a possibilidade de a racionalidade comunicativa prevalecer. Pode-se mesmo afirmar que os procedimentos que regem as decisões são debatidos e constituídos por meio de um processo coletivo e sob o controle dos sujeitos (LÜCHMANN, 2002). Por outro lado, a maior parte das reuniões não está aberta à livre participação de todos os cidadãos que, após as assembléias regionais e temáticas, não têm mais a possibilidade de autorrepresentar-se.

Em Belo Horizonte, para que uma sub-região tenha pelo menos uma obra aprovada, no mínimo $0,5 \%$ da sua população deve estar presente. Comparecimento menor implica diminuição proporcional dos recursos, sendo estes redistribuídos proporcionalmente às demais subregiões que atingirem sua quota de presença. Desse modo, a participação é aberta a todos nas rodadas das sub-regiões com incentivos institucionais para aqueles que participam. A partir daí adota-se um modelo representativo, com delegados, cuja seleção é efetuada segundo o número de associações comunitárias preestabelecidas e o de presentes nas assembléias. Os integrantes da Comforça, por sua vez, são selecionados entre os delegados em número proporcional à presença na plenária do Fórum Regional de Prioridades. A Comforça resulta de disputa de chapas. Como todas as sub-regiões devem estar representadas na Comforça eleita, se houver mais de uma chapa, sua composição deverá ser proporcional ao número de votos recebidos por cada uma.

O OP de Recife faculta a todos participarem das instâncias decisórias que compõem as primeiras fases do ciclo, iniciadas pelo credenciamento das prioridades junto à prefeitura. Para tanto, os cidadãos reúnem-se em pequenos grupos, discutem e elencam os investimentos que desejam ver realizados, registrando o resultado em formulários próprios. As prioridades credenciadas são, em um segundo momento, submetidas ao escrutínio dos cidadãos em plenárias regionais nas quais também se escolhem os delegados que terão assento no Fórum do OP. Ainda está-se, portanto, no espaço da participação ampliada e aberta ao conjunto da população, que vota, para definir as prioridades escolhidas nas referidas plenárias por meio de urnas eletrônicas. As plenárias temáticas também são abertas a todos. Nas fases efetivamente deliberativas prevalece, contudo, uma lógica não muito distinta da democracia representativa, ainda que no modelo piramidal de Macpherson (1982).

Curitiba abre suas audiências públicas orçamentárias à participação de todos os cidadãos, tanto os "não organizados" (sem vinculação associativa) quanto os "organizados". No entanto, 
observamos que a maioria dos participantes é de associações de moradores e demais organizações que pressionam o poder Executivo por melhorias dos aparelhos urbanos e demandas que passam mais por uma dimensão cooperativa com o Estado do que pela via do conflito político-ideológico (OFFE, 1989). Um aspecto importante é a presença em grande número da burocracia municipal (um representante de cada órgão de serviços da prefeitura e demais funcionários espalhados no "público") para sanar dúvidas e responder as demandas populares.

A dinâmica interna das APs é padronizada. A forma de manifestação das demandas é a Ficha de Consulta Pública, que o cidadão preenche e encaminha à mesa diretiva. No folheto, perguntase em que áreas a prefeitura deve investir e que melhorias devem ser realizadas na região. Antes de preencher suas fichas, os cidadãos têm cerca de 20 a 30 minutos para discussão. As fichas são separadas por temas, como saúde, educação, habitação etc., e encaminhadas para os técnicos da prefeitura, que respondem os questionamentos e apontamentos dos folhetos. As APs gerais, de apresentação da LDO e da LOA, que ocorrem no centro da cidade, seguem o mesmo procedimento, distinguindo-se apenas pelo fato de serem mais expositivas da base legal do orçamento, dos resultados das consultas populares, do plano diretor etc., com uma densa exposição de slides e explicações técnicas que se assemelham a uma aula sobre como se constrói o orçamento, sempre denotando aquilo que cabe no planejamento de governo.

Antes de continuar a análise em curso, uma breve digressão é necessária. A democracia deliberativa reconhece a impossibilidade de uma participação direta de todos, a todo o tempo. Admite, portanto, que a representação é inelutável, porém concebe-a para além de seu caráter tradicional nas democracias ocidentais, consubstanciado no mandato eleitoral no qual não raro é frágil o vínculo entre as preferências dos representados e a atuação dos representantes. Em um balanço teórico da questão, Avritzer (2007) sintetiza as concepções participativas da representação propugnando formas que valorizem a sociedade civil em suas esferas cotidianas, informais, discursivas, nas quais temas que poderiam encontrar dificuldades, senão barreiras de entrada nas agendas públicas, em especial nas parlamentares, circulam mais livremente. Uma das possibilidades é a de atores da sociedade civil, que comumente lidam com esses temas, exercerem papel mediador, seja vocalizando-os, em uma espécie de advocacy dos grupos sociais, seja mesmo ocupando posições em instituições híbridas, participativas e representativas, como fóruns, conselhos gestores de políticas públicas ou como as analisadas nesta pesquisa.

Considerando então a variável "condições de participação" - avaliada pela presença de "esferas amplas de participação" - poderíamos, à primeira vista, ponderar que essa presença seria fraca nos três OPs analisados, mormente se a medirmos pela possibilidade de todos os cidadãos poderem participar de todas as fases de deliberação. No entanto, é plausível relativizar tal avaliação. As instâncias representativas - fóruns do OP, COP, Comforça etc. - compõem-se de cidadãos atuantes na sociedade civil, oriundos das bases e eleitos entre todos os participantes das instâncias mais amplas, aportando temas e demandas específicas dessas mesmas bases. Somemos a isso as formas de controle da participação dos representantes, como, por exemplo, a participação do cidadão comum, com direito à voz, nos COPs, e tem-se uma configuração que, potencialmente, favorece um caráter mais substantivo à representação e à própria participação defendida pela teoria. Em contraste, Curitiba abre todas as audiências públicas para todos, indistintamente. Basta chegar, cadastrar-se e participar. $\mathrm{O}$ limite reside no alcance da participação, meramente consultiva.

\section{III.1.3. Discussão}

Todas as instâncias do OP da capital gaúcha prevêem uma discussão ampla e livre pelos participantes. Para cada instância há uma coordenação que conduz as reuniões, integrada por membros da prefeitura municipal de Porto Alegre e da sociedade civil, com maioria desta. Prevê-se rodízio entre os integrantes na coordenação das reuniões, o que formalmente (na prática pode ser diferente) reduz possíveis vieses em prol de um ou outro segmento na condução dos trabalhos. Há regras para garantir que diversas pessoas falem, como a que limita em dois minutos o tempo para cada intervenção nas reuniões do COP. As decisões são coletivas, sendo tomadas após a discussão de cada ponto de pauta, por meio de votação entre os sujeitos com direito a voto. $\mathrm{O}$ problema é o alcance do que cada uma das instâncias delibera. Como as assembléias realizam- 
se em rodada única, o diálogo fica restrito, assim como sua pauta: discute-se a prestação de contas do exercício anterior e elegem-se as prioridades temáticas, conselheiros e delegados, todos ratificados na Assembléia Municipal, na qual os conselheiros tomam posse e entrega-se a hierarquização das obras e serviços.

Devido ao formato descentralizado em UPs e sub-regiões, o debate público dos problemas da cidade de Belo Horizonte possui capilaridade, porém com forte presença da burocracia da PMBH, mediante o Grupo Gerencial do OP, responsável por formulá-lo, implementá-lo, executá-lo e acompanhá-lo. O Grupo reúne mensalmente gestores executivos e técnicos dos órgãos municipais para discutir e encaminhar as questões e tarefas. Durante a discussão pública e as deliberações, o quadro funcional da prefeitura é reforçado por técnicos contratados para a realização de vistorias e a estimativa de custos das obras. Destaca-se, entretanto, o papel das Caravanas das Prioridades: um intenso processo de negociações no qual, em muitos casos, os delegados, após visitarem os investimentos, abrem mão de suas próprias demandas para acatarem as de outros em situação mais urgente. A razão comunicativa é assim imperativa, pois os agentes "colocam-se no lugar do outro", de seus pares, para compreenderem as necessidades dos empreendimentos solicitados.

Outro elemento a destacar em Belo Horizonte é o mecanismo já mencionado, que condiciona a integralidade dos investimentos à participação de $0,5 \%$ da população da sub-região. Isso é importante porque o desenho institucional fomenta a discussão nas vizinhanças e que os cidadãos convidem outros cidadãos a discutir suas demandas e prioridades, inicialmente de maneira informal, e a levá-las ao espaço participativo formal, aspecto bastante caro à democracia deliberativa.

As instâncias do OP de Recife possuem regras de funcionamento que permitem a manifestação livre dos cidadãos, inclusive no Fórum do OP, instância representativa em que todos podem, contudo, falar livremente, desde que se inscrevam na coordenação das reuniões. Restrições ao direito à fala são encontradas no COP - podem manifestar-se apenas seus membros, representantes regionais e temáticos. Os demais cidadãos que queiram exprimir-se nas reuniões do COP precisam de autorização do conselho. Todavia, prevalecem espaços em que a discussão é amplamente possibilitada. Como ocorre em Belo Horizonte, o desenho institucional incentiva a discussão em espaços informais, ao obrigar a formação de pequenos grupos nas vizinhanças para a eleição das prioridades de investimento.

Em todas as APs de Curitiba, os procedimentos comunicativos dão-se por meio de microfones monopolisticamente coordenados pela mesa diretiva. Em algumas poucas ocasiões, há microfones sem fio que vão até o público. Vereadores e demais autoridades políticas que transitam entre uma e outra AP possuem prerrogativa de fala. Os feedbacks dos técnicos quase sempre têm um caráter justificador, tanto sobre alguma decisão tomada, quanto sobre a possibilidade de atender ou não uma demanda. $\mathrm{Na}$ maioria dos casos o tom discursivo é eminentemente técnico, fato que faz prevalecer o silêncio após as explanações. A comunicação é, portanto, plasmada pelo discurso tecnocrático, prevalecendo uma desconstrução dos argumentos das demandas sociais e da possibilidade da deliberação em si, sendo ausentes espaços e fluxos de debates e negociações. Um exemplo: quando as APs chegam ao horário de término, os administradores das regionais informam que todas as "sugestões e reivindicações serão encaminhadas à Seplan e serão respondidas via fone ou $e$-mail". Caso contrário, "procurem a Rua da Cidadania". Fatos como esses indicam um compromisso maior com o horário, tempo racionalizado e controlado, do que com o processo discursivo e deliberativo.

Às vezes, os feedbacks do poder Executivo municipal têm viés de tutela moral e, quando os participantes não "se comportam adequadamente", manifestando contestações, vaias, murmúrios etc., os administradores não hesitam em enquadrar os sujeitos com respostas secas, diretas e, às vezes, irônicas: "já foi respondido!”, “ok, anotado, colocado seu ponto. Próxima pergunta?", "esse assunto já foi abordado" etc.. Tentativas de debate e tréplicas ou quando as conversas tornam-se mais ríspidas, geram exacerbação dos técnicos pelo

\footnotetext{
7 Ruas da Cidadania são espaços construídos pela Prefeitura de Curitiba nos bairros, em geral junto a terminais de transporte coletivo, que concentram serviços públicos que, desse modo, são ofertados de maneira descentralizada.
} 
respeito à ordem das intervenções e às "perguntas que foram feitas pelas Fichas de Consultas!".

A variável "discussão" - aqui mensurada pela presença de "espaços e fluxos de debates e negociações" - tem comportamento bastante distinto nos arranjos participativos estudados. Nos OPs de Belo Horizonte e Recife eles têm forte presença, pois além de estruturas formais abertas à fala dos cidadãos, os desenhos institucionais dos OPs dessas cidades propiciam amplos fluxos comunicativos em espaços informais, o que se verifica nas demais cidades de maneira difusa, pouco incentivada pelo desenho em si. Em Porto Alegre, espaços e fluxos de debates e negociações existem, mas sua presença é fraca, principalmente após a supressão da segunda rodada de assembléias regionais e temáticas. Em Curitiba, embora eles até existam, são de tal modo tutelados e limitados pelo poder público que se pode afirmar sua ausência como esferas públicas como as preconizadas pela democracia deliberativa.

\section{III.1.4. Deliberação}

O OP de Porto Alegre é uma instância cujas decisões têm amplo escopo. No entanto, o corpo burocrático do governo municipal acaba por exercer forte influência, na medida em que a agregação de preferências por meio da escolha e hierarquização das demandas obedece a critérios eminentemente técnicos (LÜCHMANN, 2002). Outro limite ao poder de deliberação é o baixo percentual do orçamento público objeto de discussão, que nunca ultrapassou $10 \%$ do Orçamento Global, principalmente devido a limites legais como despesas vinculadas, com pessoal, custeio etc. Trata-se de um aspecto importante, que reduz as possibilidades de os governos investirem nas áreas mais pobres da cidade (SOUZA, 2001), gerando "escolhas trágicas" entre demandas prioritárias (LÜCHMANN, 2002). Ademais, como alerta Avritzer (2002b), o OPdecide a alocação dos recursos, mas não ataca o ponto crucial da elaboração das próprias políticas municipais, totalmente a cargo do poder Executivo, não apenas em Porto Alegre, mas em todas as capitais estudadas.

Buscando equilibrar planejamento urbano e participação, a prefeitura de Belo Horizonte adotou gradualmente regras e critérios técnicos formados por índices, coeficientes e pontuações. Os principais exemplos são o Índice de Qualidade de Vida Urbana (IQVU) e as Áreas Prioritárias de inclusão urbano-social - compostos por vários indicadores de educação, saúde, infraestrutura urbana, habitação etc. Implantados respectivamente em 2000 e 2003, permitem identificar precisamente as regiões que mais necessitam de infraestrutura. Belo Horizonte coloca, assim, desafios à discussão das experiências participativas como espaços para a deliberação racional e formação de preferências, pois os efeitos distributivos do OP não teriam sido alcançados sem a introdução-correção gradual das regras e critérios técnicos. O formato desse OP sugere que a ampliação da capacidade de execução e eficiência gerencial foi atingida à custa do recrudescimento do poder de agenda do poder Executivo municipal (PIRES, 2009). De todo modo, a dinâmica registrada em Belo Horizonte permite que os cidadãos afetem as decisões do poder público sobre o orçamento, com regras e critérios claros, mesmo que esses imponham e favoreçam determinadas decisões.

O OP de Recife, assim como os de Porto Alegre e Belo Horizonte, é uma estrutura de participação com poder deliberativo, cujas decisões vinculam parte do orçamento público às preferências manifestas dos cidadãos. Vale a ressalva, contudo, de que a parcela do orçamento em relação à qual os cidadãos efetivamente decidem é pouco significativa. Segundo Costa (2010), até 2004 pouco mais de $5 \%$ da LOA foram objeto de deliberação, ainda que esse valor represente a integralidade dos recursos para investimento, sendo apontadas, para a capital pernambucana, limitações semelhantes às presentes em Porto Alegre.

As APs de Curitiba não têm caráter decisório, apenas consultivo, sem garantias de que elas dirijam as ações da PMC. É certo que as influenciam, mas em um grau impossível de medir-se. A decisão sobre a agenda de ações da prefeitura é prerrogativa exclusiva desta, mais especificamente da Seplan (vinculada diretamente ao Instituto de Pesquisa e Planejamento Urbano de Curitiba (Ippuc)) e da Secretária Municipal de Finanças (SMF). Da mesma forma, a prefeitura não disponibiliza informações claras sobre o quanto do orçamento é destinado para as sugestões apresentadas nas APs. Em 2010, por exemplo, 8\% do total da receita líquida foi prevista para a aplicação de Investimentos do Município, isto é, para as "prioridades estabelecidas no Plano de Governo 2009-2012 e uma série de proposições 
apresentadas nas audiências públicas promovidas nas nove administrações regionais" (CURITIBA, 2009; sem grifos no original), não havendo, contudo, indicação de quanto exatamente foi alocado para atendimento das demandas apresentadas nas APs.

Avaliando o comportamento da variável "deliberação", mediante a "delegação efetiva de poder", é possível afirmar que sua presença é fraca nos três OPs em apreço, sobretudo porque os percentuais dos orçamentos sobre os quais se delibera são bastante tímidos e também porque, no limite, as prefeituras jogam um papel determinante nos destinos dos recursos e na própria construção das políticas. Em Curitiba, não há deliberação. Quando muito, pode-se designar o processo de consultivo ou, como prefere uma autora de trabalho recente sobre as APs da cidade, de ouvidoria (AZOLIN, 2011).

A Tabela 1 sintetiza o comportamento das variáveis que compõem a dimensão "desenho institucional".

\begin{tabular}{|c|c|c|c|c|c|}
\hline \multirow[b]{2}{*}{ VARIÁVEL } & \multirow{2}{*}{$\begin{array}{l}\text { AUSÊNCIA (0), PRESENCCA } \\
\text { FRACA (1), PRESENÇA } \\
\text { FORTE (2) DE: }\end{array}$} & \multicolumn{4}{|c|}{ CIDADE } \\
\hline & & $\begin{array}{c}\text { PORTO } \\
\text { ALEGRE }\end{array}$ & $\begin{array}{c}\text { BELO } \\
\text { HORIZONTE }\end{array}$ & RECIFE & CURITIBA \\
\hline $\begin{array}{l}\text { Arcabouço institucional } \\
\text { e funcionamento }\end{array}$ & $\begin{array}{l}\text { Formulação das regras } \\
\text { pelos cidadãos }\end{array}$ & 1 & 2 & 1 & 0 \\
\hline $\begin{array}{l}\text { Condições de } \\
\text { participação }\end{array}$ & $\begin{array}{l}\text { Esferas amplas (para toda } \\
\text { a sociedade) de } \\
\text { participação }\end{array}$ & 2 & 2 & 2 & 2 \\
\hline Discussão & $\begin{array}{l}\text { Espaços e fluxos de } \\
\text { debates e negociações }\end{array}$ & 1 & 2 & 2 & 0 \\
\hline Deliberação & $\begin{array}{l}\text { Delegação efetiva de } \\
\text { poder }\end{array}$ & 1 & 1 & 1 & 0 \\
\hline Total de pontos (máximo & & 5 & 7 & 6 & 2 \\
\hline
\end{tabular}

FONTE: os autores, a partir de Belo Horizonte (2007; 2011), Curitiba (2009; 2011), Porto Alegre (2010) e Recife (2011).

\section{III.2. Contexto}

\section{III.2.1. Grau de associativismo}

Associativismo é uma variável de difícil mensuração. Diante da inexistência de uma pesquisa nacional que afira o grau de participação associativa das populações de todos os municípios, pesquisadores procuram estabelecer proxies, como Avritzer et alii (2007), que utilizaram o cálculo da razão entre o número de associações e a população de uma cidade, em pesquisa, que incluiu Recife, sobre $o$ associativismo civil no Nordeste Brasileiro. Utilizamos o cálculo do referido estudo para as outras capitais, no presente trabalho, e usando dados das prefeituras, obtivemos os índices constantes na Tabela 2.
TABELA 2 - ÍNDICES DE PARTICIPAÇÃO EM ASSOCIAÇÕES (IPA) NAS CAPITAIS PESQUISADAS ( ${ }^{\circ}$ DE PARTICIPANTES POR MIL HAB.)

\begin{tabular}{|l|l|}
\hline CIDADE & IPA \\
\hline Porto Alegre & 0,51 \\
Belo Horizonte & 1,13 \\
Recife & 1,50 \\
Curitiba & 0,50 \\
\hline
\end{tabular}

FONTE: os autores, a partir de Avritzer et alii (2007), Belo Horizonte (2007; 2011), Curitiba (2009; 2011), Porto Alegre (2010), Brasil. Datasus (2011) e Recife (2011).

Esses resultados apontam para um nível comparativamente alto de associativismo nas capitais mineira e pernambucana e para um resultado surpreendentemente modesto para Porto Alegre, cujo índice assemelha-se ao de Curitiba. Reconhecemos a fragilidade do indicador, pois ele 
pouco diz sobre a natureza das associações, seu processo de formação e o tipo de relação que elas mantêm com os poderes executivos. Todavia, na falta de outro índice que efetivamente permita comparações entre todas as cidades investigadas, utilizamo-lo como pano de fundo de nossas análises.

Estudos sobre participação política em Porto Alegre apontam a presença de um forte grau de organização da sociedade civil (SANTOS, 1998; SETZLER, 2000; AVRITZER, 2002b). Os índices acima assinalam, no entanto, a necessidade de relativizar-se a afirmação dessa cidade como a Meca brasileira da participação e do civismo. A capital gaúcha registra os mesmos tímidos indicadores de participação política organizada presentes em outras partes do país, constatação reforçada pelos resultados de investigação sobre a capital gaúcha, baseada em survey (VISCARRA, 2010). É provável que, na atualidade, a cidade possua um conjunto relativamente pequeno de militantes com múltiplas afiliações, que passa uma primeira impressão de forte ebulição da sociedade civil, rapidamente dissipada quando se considera o tecido social em sua totalidade.

O índice de participação em associações de Belo Horizonte é mais que o dobro do de Porto Alegre, o que sugeriria um associativismo civil bastante fértil. No entanto, Avritzer (2002b) registra diferenças importantes entre as duas capitais. Enquanto entre participantes do OP da capital gaúcha a mobilização das comunidades é apontada como o principal fator para a obtenção de benefícios materiais, na capital mineira, relações pessoais com políticos é o modo mais comumente apontado para a obtenção desses benefícios. $\mathrm{O}$ motivo residiria no fato de que "Belo Horizonte tem uma formação histórica mais conservadora, com menos mobilização e maior presença dos mediadores políticos" (idem, p. 37). De todo modo, havia um forte associativismo comunitário nas duas cidades antes da implantação dos desenhos. O OP torna-se viável, portanto, porque as suas assembléias locais herdaram práticas das associações de moradores de Belo Horizonte e Porto Alegre desde o final dos anos 1970 (idem), mesmo que uma parcela minoritária de seus moradores participasse efetivamente das associações.

Recife destaca-se pelo alto índice de participação em associações. No final dos anos
1970, a cidade seguiu uma dinâmica semelhante à das capitais do Centro-Sul, no bojo do novo associativismo civil, relacionado a novos movimentos sociais e à luta pela redemocratização. O período é caracterizado pelo fortalecimento de associações de moradores que rompem o padrão clientelista de relação com os governos, clamando pela conquista de direitos de cidadania, processo que culmina com a eleição, em 1985, de Jarbas Vasconcelos, liderando uma frente de centroesquerda, nas primeiras eleições para prefeituras de capitais dos estados após o regime militar. Em seu mandato, iriam desenvolver-se as experiências participativas que constituirão o futuro OP recifense (SILVA, 2003).

Curitiba é, dentre as cidades investigadas, a que apresenta o menor índice de participação em associações, com resultado muito próximo ao de Porto Alegre. Some-se isso ao padrão autoritário de gestão municipal e desvendam-se os porquês da debilidade em constituir-se um associativismo comunitário independente, que induza experiências participativas. Na capital paranaense, essas acabam por ser organizadas e implantadas de cima para baixo, pelo poder Executivo municipal que, ademais, dificilmente aceita movimentos não formalizados como interlocutores. Uma hipótese a ser verificada, em trabalhos futuros, é se a cidade poderá vivenciar uma inflexão na sua dinâmica associativa com as APs. Em nossas observações, notamos que as audiências podem estar a fomentar um movimento de vizinhança mais autônomo, menos preso aos ditames do clientelismo em comparação com um histórico de associações tuteladas pelo poder Executivo municipal (CLEMENTE, 2008; 2011).

À luz das análises acima, podemos averiguar o desempenho da variável "associativismo", aferida pelos "níveis de associativismo que sustentem os desenhos". Inferimos que Recife e Belo Horizonte são as capitais investigadas onde tais níveis têm forte presença, mesmo com as características clientelísticas mais intensas na capital mineira. Em Porto Alegre, os níveis são débeis. Aparentemente, as expressões associativas fervilharam em décadas passadas e foram importantes para a constituição, mas não para manutenção da participação social, o que vem adquirindo contornos dramáticos, como se verá adiante. Curitiba possui, obviamente, um campo associativo, mas que não sustentou nem sustenta as audiências públicas orçamentárias, isto é, não 
como esferas públicas de deliberação.

\section{III.2.2. Conformação dos grupos políticos}

Para Souza (2001), o OP tem relação direta com o crescimento dos governos locais de esquerda desde o final dos anos 1980, ainda que experiências participativas tivessem ocorrido desde o regime militar em cidades administradas pela oposição. Matthaeus (1995) chega a afirmar a impossibilidade de sua implantação por partidos que não sejam de esquerda, mesmo que agremiações à direita do espectro político possam manter o OP quando vencem eleições em cidades onde ele já tenha sido instituído, embora, geralmente, com modificações que reduzem seu escopo.

Nylen (2000) aponta as razões para essa primazia da esquerda, em face dos objetivos que seus governos colocam-se: $(i)$ inversão de prioridades, no sentido de favorecer os pobres; (ii) o empoderamento, pelo qual os cidadãos tomam consciência das desigualdades e injustiças existentes e enfrentam-nas por meio da ação coletiva visando alcançar reformas progressivas; (iii) o autogoverno local. O OP depende, portanto, da vontade política do grupo que se encontra no governo da cidade e não da obediência a imperativos legais vindos de um ente federativo superior, como as APs.

Em Porto Alegre, o OP resultou de uma fermentação de reivindicações participativas de grupos e tendências progressitas, das bases comunitárias que convergiam na União das Associações de Moradores de Porto Alegre (Uampa) fundada em 1983 e profundamente identificada com as lutas pela democratização do Estado e a criação de espaços de democracia direta. O momento culminante foi, entretanto, a conquista da prefeitura pelo PT, em 1988, com Olívio Dutra à frente da chapa vencedora (AVRITZER, 2002b). Naquele momento, o PT possuía mais conexões com as grassroots, levando ao aparato governamental algumas de suas características, sendo a discussão aberta e exaustiva uma das mais marcantes. O OP foi, então, implantado no ano seguinte e funciona até o presente. A experiência porto-alegrense é, todavia, ilustrativa de como os grupos que se encontram no poder Executivo afetam diretamente o desenho e o funcionamento da instituição participativa. Em 2009, José Fogaça, candidato oposicionista eleito no ano anterior, modifica o procedimento deliberativo do OP, principalmente suprimindo a segunda rodada de assembléias regionais e temáticas. Justificada como uma medida simplificadora da participação, o efeito prático foi um esvaziamento do OP, que pode ser constatado pela redução paulatina e significativa no número de participantes.

Na capital mineira, o PT venceu as eleições em 1992, com Patrus Ananias, e em 1993 colocou em prática o OP. A partir de 1997, a cidade foi administrada pelo Partido Socialista Brasileiro (PSB) do Prefeito Célio de Castro, que deu continuidade ao desenho participativo. $\mathrm{Na}$ realidade, em 1996, o PT lançara a candidatura de Virgílio Guimarães, contra a vontade de Patrus, que preferia seu vice, Célio de Castro, vencedor do pleito. Ou seja, não houve ruptura de fato.

O PT retorna à PMBH em 2005, mas em 2009 o PSB volta à direção da cidade. Houve, assim, uma independência relativa da credibilidade do OP em relação ao PT. Essa credibilidade foi construída na relação entre a administração pública e atores sociais durante a execução do formato (idem). Todavia, a Secretaria Municipal de Planejamento teve um papel fundamental na concepção e na execução do OP em Belo Horizonte. O órgão, detentor de grande força política e do controle de importantes recursos críticos de natureza orçamentária, criou um engenhoso sistema de planejamento combinado com participação popular (ver subseção III.4.2, adiante).

A experiência da capital mineira aponta para a compatibilização de diferentes burocracias por meio de negociações. As atividades de coordenação exercidas pela Secretaria de Planejamento concentraram-se nas fronteiras e interfaces dos órgãos e políticas governamentais, parecendo correto afirmar que antes de abrir a discussão com os setores organizados da sociedade, logrou-se pactuar, internamente à Prefeitura, uma proposta consensual de OP (PIRES, 2009). Ingrediente adicional à análise em curso é o atual Prefeito, Maurício Lacerda (PSB), ter sido eleito com apoio do PTe do Partido da Social Democracia Brasileira (PSDB), do ex-Prefeito Fernando Pimentel e do ex-Governador Aécio Neves, respectivamente. Pode-se dizer que Belo Horizonte encontra-se na confluência entre participacionismo e gerencialismo, talvez influenciada pelo fato de a governança do poder Executivo municipal resultar de uma rara aliança entre esses dois partidos em grandes cidades. 
A tradição política de Recife, comumente caracterizada pelo intenso associativismo civil e a expressiva densidade social e eleitoral de grupos identificados com a esquerda, também é apontada como diferencial e base de instituições participativas bem sucedidas, cuja constituição remonta a um período anterior ao golpe militar de 1964, fins da década de 1950, início da de 1960, quando a cidade foi governada pela Frente do Recife, tendo, à dianteira, Miguel Arraes e Pelópidas da Silveira, ainda que em uma chave populista (SILVA, 2003; BRAGA \& BRAGA, 2008). Em 1985, é eleito o Prefeito Jarbas Vasconcelos, figura de proa do autodenominado "MDB autêntico", a ala do partido mais combativa ao regime militar e que, com o retorno do pluripartidarismo, migrou, em geral, para partidos de esquerda como o PDT, o PCB, o PC do B, PT e o próprio PSB, sigla que abrigou Jarbas quando este não obteve legenda no $\mathrm{PMDB}^{8}$ em 1985.

Resultado de uma coalizão de centro-esquerda (a "Frente Popular do Recife"), o mandato culminou na implantação do Programa Prefeitura nos Bairros (PPB), o qual, superando os canais tradicionais de distribuição dos recursos e de captura dos inputs societais, viria a ser o embrião do OP no Recife. Com PPB, o poder Executivo municipal estabelece uma interlocução direta com as lideranças comunitárias e suas organizações. Em 1993, Jarbas Vasconcelos, já de volta ao PMDB, retorna à prefeitura, agora sustentado, no entanto, por uma coalizão de centro-direita em função de mudanças na correlação das forças políticas pernambucanas. Destaca-se, nesse período, a implantação do Orçamento Participativo como desdobramento do PPB, que tem continuidade no mandato seguinte (1997-2000), de Roberto Magalhães, do Partido da Frente Liberal (PFL), apoiado por Jarbas. Porém, como em outros municípios, a inflexão nos processos participativos é a chegada do PT ao poder Executivo municipal, em 2001, com o Prefeito João Paulo. Há, a partir de então, alterações no desenho institucional e no funcionamento do OP recifense, inspiradas em Porto Alegre, ainda que

\footnotetext{
8 Respectivamente: Partido Democrático Trabalhista (PDT), Partido Comunista Brasileiro (PCB), Partido Comunista do Brasil (PC do B), Partido dos Trabalhadores (PT), Partido Socialista Brasileiro (PSB) e Partido do Movimento Democrático Brasileiro (PMDB).
}

Olívio Dutra tenha inicialmente se inspirado no PPB do Recife (AZEVEDO \& ANASTASIA, 2002).

Em Curitiba, o grupo político que manteve sua hegemonia até 2004 sobre a administração pública originou-se do próprio Estado BurocráticoAutoritário. "Trata-se de um grupo que funda sua legitimidade, principalmente, "no discurso da competência' técnica no planejamento urbano" (SOUZA, 2003, p. 5), vale dizer, da intervenção no reordenamento espacial da cidade com base em uma argumentação técnico-racional. Houve apenas uma rápida interrupção dessa hegemonia, entre os anos de 1983 e 1988, quando a prefeitura municipal foi administrada pelo PMDB.

As APs orçamentárias começaram em 2001, no mandato de Cássio Taniguchi (PFL), respondendo aos já discutidos constrangimentos normativo-institucionais. Todavia, as audiências só adquirem importância quando Beto Richa, do PSDB, venceu as eleições municipais de 2004, sobre o candidato do PT, Ângelo Vanhoni. Durante o período eleitoral, muitos debates foram realizados em torno da tendência tecnocrática do poder Executivo municipal e o candidato petista apresentou a proposta de implantação do OP. Findo o pleito, o Prefeito, mesmo sendo o candidato situacionista e Vice-Prefeito da gestão que havia acabado de terminar, procurou realizar uma gestão mais próxima da comunidade, ou seja, Richa procurou politizar as formas de comunicação e interação com a sociedade civil curitibana. É nesse contexto que desde 2005 as APs ganham destaque em Curitiba. Trata-se de um requisito legal que passou a receber forte conotação de teor participativo no que diz respeito à construção da agenda orçamentária da cidade. A gestão do PSDB em Curitiba mostra-se emblemática, uma vez que ela representa uma forma quase que estratégica de combinação entre um modelo tecnocrático e um modelo voltado à maior participação societária, até devido às pressões provenientes da esfera pública. O fato de Beto Richa ser filho de José Richa - político ligado aos movimentos da redemocratização - mas também ter sido VicePrefeito de Cássio Taniguchi, aponta nessa direção combinatória, quase "híbrida".

Taniguchi é o exemplo acabado de um prefeito tecnocrata em Curitiba, juntamente com seu padrinho político, Jaime Lerner. Arquiteto e urbanista de fama mundial, Lerner participou da 
criação do Instituto de Pesquisa e Planejamento Urbano de Curitiba (Ippuc), na década de 1960. Em 1965, foi responsável pelo Plano Diretor da cidade, que a consagrou como "cidade modelo". Filiou-se à Aliança Renovadora Nacional (Arena) em 1971. Nomeado Prefeito de Curitiba por duas vezes e eleito em 1988, já na Nova República, por sufrágio popular pelo PDT, em 1994, venceu as eleições para o governo do Paraná, sendo reconduzido ao cargo em 1998, pelo PFL.

Na gestão de Beto Richa, aglutinaram-se, nos cargos de primeiro escalão, tanto nomes que pertenceram ao antigo MDB quanto nomes historicamente ligados ao grupo que se formou ao redor de Lerner (NAZARENO, 2005). Toda essa constelação de forças teve impacto na forma pela qual se formaram as APs, bem como a sua dinâmica interna, na qual há a reprodução de um padrão comportamental, a saber: a legitimação das decisões pelo discurso da competência técnica.

Os três OPs, de modo mais ou menos evidente, resultam de pressões advindas das bases sociais que, especialmente na década de 1980, pressionaram os poderes executivos municipais a criarem canais mais diretos de comunicação e absorção de demandas. Tais pressões por si só seriam, no entanto, insuficientes. $\mathrm{O}$ fato de elas encontrarem, à frente dos poderes executivos municipais, forças políticas (notadamente o PT) que tinham entre seus objetivos declarados a democratização da esfera pública mediante a introdução de desenhos participativos, foi essencial em Porto Alegre, Belo Horizonte e Recife. A conjugação desses dois fatores - pressões da sociedade civil e prefeituras governadas por determinadas vertentes do espectro políticoideológico - permite-nos constatar a presença, nas três capitais, de processos bottom-up na implantação do desenho participativo, com que medimos a variável conformação dos grupos políticos, ainda que essa presença seja fraca na capital mineira, em função do papel exercido pela burocracia municipal. Curitiba apresenta-se como um caso desviante das referidas cidades, na medida em que tais processos estão ausentes. A Tabela 3 sintetiza o comportamento das variáveis que compõem a dimensão "Contexto".

TABELA3 - COMPORTAMENTO DAS VARIÁVEIS DA DIMENSÃO “CONTEXTO”

\begin{tabular}{|l|c|c|c|c|c|}
\hline \multirow{2}{*}{ VARIÁvEL } & $\begin{array}{c}\text { AUSÊNCIA (0), PRESENÇA } \\
\text { FRACA (1), PRESENÇA } \\
\text { FORTE (2) DE: }\end{array}$ & $\begin{array}{c}\text { PORTO } \\
\text { ALEGRE }\end{array}$ & $\begin{array}{c}\text { BELO } \\
\text { HORIZONTE }\end{array}$ & RECIFE & CURITIBA \\
\hline Associativismo & $\begin{array}{c}\text { Níveis de associativismo } \\
\text { que sustentam os } \\
\text { desenhos }\end{array}$ & 1 & 2 & 2 & 0 \\
$\begin{array}{l}\text { Conformação dos } \\
\text { grupos políticos }\end{array}$ & $\begin{array}{c}\text { Processos botton-up na } \\
\text { implantação do desenho }\end{array}$ & 2 & 1 & 2 & 0 \\
Total de pontos (máximo 4) & & 3 & 3 & 4 & 0 \\
\hline
\end{tabular}

FONTE: os autores, a partir de Belo Horizonte (2007; 2011), Curitiba (2009; 2011), Porto Alegre (2010), Brasil. Datasus (2011) e Recife (2011).

\section{III.3. Política}

\section{III.3.1. Representação}

Souza (2001), a partir de sua revisão de literatura sobre o OP de Porto Alegre, afirma que este possibilita um empoderamento pelo qual os cidadãos, inclusive os mais pobres, têm acesso ao processo decisório local, a despeito de sua indução e coordenação pelos governos. Por causa da redistribuição de recursos, consubstanciada em incrementos materiais e simbólicos nas comunidades pobres, o OP estaria a promover uma democracia afirmativa nessa cidade, reduzindo tradicionais assimetrias (NAVARRO, 1999). Atendo-nos exclusivamente aos conselheiros, sujeitos com maior poder de decisão entre todos os participantes do ciclo, a composição do COP em 2002 segundo o gênero - 52,5\% mulheres e $47,5 \%$ homens - era praticamente idêntica à composição da sociedade brasileira em geral. Quanto à renda familiar, para um salário mínimo (SM) de R \$ 200 à época, 21,7\% ganhavam menos de dois SM, enquanto $28,3 \%$, entre dois e quatro SM. Ou seja, metade dos conselheiros tinha uma 
renda familiar mensal de até quatro SM. Outro indicador que destacamos é a escolaridade: a soma dos que tinham até o Ensino fundamental (incompleto: 27,9\%; completo: $11,5 \%$ ) aproximava-se dos 40\% (CIDADE, 2003).

Considerando o poder de deliberação do COP e comparando os números acima com os de qualquer outra instância de decisão sobre alocação de recursos (p. ex., câmaras municipais), o OP promove a inclusão de estratos historicamente marginalizados das decisões políticas, que nele estão diretamente representados. Ainda há de ressaltar-se o corte temático do OP de Porto Alegre, que aumenta a possibilidade de públicos múltiplos participarem dos processos de democratização da gestão pública. Aparecem, contudo, indícios de que o potencial inclusivo do OP pode ter atingido seu limite. Informe do Banco Mundial de 2008 apresenta vários problemas na nova fase de execução do OP (a partir do mandato de José Fogaça), como o declínio da participação dos muito pobres e a sub-representação dos jovens nestas instâncias (GUGLIANO, 2009).

O OP de Belo Horizonte está focado na distribuição de recursos e benefícios materiais, não apresentando corte temático como os de Porto Alegre e Recife. Áreas como educação, saúde e proteção social são de exclusiva competência da administração municipal, não sendo contempladas pelo formato participativo da capital mineira, restringindo-se, desse modo, o alcance da sua representatividade (AVRITZER, 2002b). Em geral, os participantes são lideranças das comunidades, fato que é reforçado pela própria regra que define os delegados, pois cada associação comunitária legalmente estabelecida tem direito a um delegado e um suplente, tornando a representação bastante homogênea. Entretanto, não há motivos para crer que não tenha ocorrido, em Belo Horizonte, o aumento da representatividade dos setores historicamente marginalizados, na medida em que o próprio critério das Áreas Prioritárias aponta na direção de procurar "corrigir" distorções sociais e garantir direitos de cidadania.

No OP do Recife as regras induzem a que vários grupos sociais componham as diversas instâncias da instituição participativa. Os dois tipos de plenárias, como na capital gaúcha - regionais e temáticas - atraem sujeitos distintos à medida de seus variados interesses, no primeiro caso, relacionados às necessidades do local de moradia e, no segundo, a questões mais amplas, que afetam o conjunto dos cidadãos. Noutros termos, o desenho institucional abarca uma multiplicidade de públicos que alarga a possibilidade de participação de estratos sociais os mais diversos e de diferentes status socioeconômicos, cumprindo a propalada função do OP de incluir segmentos tradicionalmente excluídos das políticas públicas em geral e dos processos decisórios em particular. Prova disso é que as mulheres foram maioria dos participantes do OP, tanto nas plenárias temáticas quanto regionais, entre 2001 e 2007. A média foi de $58 \%$ de mulheres e $42 \%$ de homens. O problema reside, ainda, nos espaços de poder delegados-delegadas e conselheiros-conselheiras do COP - ocupados majoritariamente por homens (SOS CORPO, 2008).

Faltam dados mais precisos para Curitiba, que permitam avaliar o grau da representatividade alcançada dentro das APs. A carência de informação sobrevém de dois motivos: primeiro, porque a prefeitura parece não demonstrar preocupação em identificar e estratificar os sujeitos que ocupam esse espaço público. Isso indica certa precariedade dos procedimentos, pois a PMC, até o presente momento, não desenvolveu ou pelo menos não divulgou a existência de instrumento que permitisse levantar o perfil socioeconômico do público das APs; segundo, por tratar-se de um fenômeno relativamente recente, existindo nos moldes atuais desde 2005, são raros os estudos sobre esse objeto. Observando as audiências, constatamos a presença de pessoas de grupos sociais diversos, ainda que a maioria represente associações de moradores politicamente ligadas à prefeitura.

Se pessoas de diferentes estratos socioeconômicos e relacionadas a múltiplas temáticas participam de uma instituição participativa, é porque elas encontram condições propícias para terem suas posições (vale dizer, suas narrativas) e demandas consideradas, enxergando um sentido em participar e adquirindo um sentimento de eficácia política. São, dessa forma, atendidas em sua necessidade de representatividade em instâncias decisórias, diretamente ou com a mediação de expressões organizadas da sociedade civil, que fazem sua advocacy, como propõe Avritzer (2007).

Considerando-se a variável "representação", mediante a presença de "públicos múltiplos", 
conclui-se que essa presença é forte em Porto Alegre e Recife, sobretudo em função das assembléias temáticas. Em Belo Horizonte e Curitiba, uma diversidade de sujeitos comparece, no entanto, sem a mesma possibilidade que a existente, nas duas outras cidades, de deliberar sobre questões relacionadas às suas identidades específicas, em face do desenho das instituições participativas, voltado a critérios geográficos. De todo modo, é importante ressaltar que nas quatro cidades pesquisadas a existência dos espaços de participação configura estruturas de oportunidade política para sujeitos historicamente alijados das tomadas de decisão.

\section{III.3.2. Participação}

Uma decorrência importante da democratização da gestão pública são grupos dominados adquirirem um sentimento de eficácia política, de que sua presença conta e traz benefícios coletivos (seletivos também). Tal fato comprova-se emPorto Alegre pelo significativo aumento de $2600 \%$ no número de participantes nas plenárias entre 1990 e 2002 (CIDADE, 2003). No entanto, Gugliano (2009) chama a atenção para a possibilidade de a coalizão político-partidária que assumiu a PMPA em 2005 converter o OP em um espaço de referendo das políticas elaboradas pelo governo. $\mathrm{O}$ autor lembra que o número de presentes nas assembléias do OP foi 1300 em 1989; 14267 em 1995; 21805 em 2001; e precisamente a partir deste último ano, a presença começou a declinar (ainda na gestão petista) e, no ano de 2004, 13 200 cidadãos compareceram às assembléias. $\mathrm{Na}$ gestão de Fogaça houve uma leve recuperação no primeiro ano de governo, com 14376 participantes, em 2005. Contudo, novamente o número reduziu-se em 2006, com 11097 participantes. A diminuição no afluxo parece indicar uma perda de fôlego do OP portoalegrense, em função dos problemas mencionados anteriormente, relacionados à sub-representação de algumas camadas populacionais que se lograra incorporar ao longo do tempo.

Belo Horizonte apresenta uma média de participação relativamente maior do que a de Porto Alegre. Segundo dados da URB-AL (BELO HORIZONTE, 2007) os números entre os anos de 1994 a 1998 (no período em que o ciclo era anual) são os seguintes: 1994: 15 216; 1995: 26 823; 1996: 38 508; 1997: 33 695; 1998: 20678. O ápice na capital mineira adveio em 1996, apresentando uma queda logo em seguida. Para o período no qual o ciclo tornou-se bianual, temos: 1999-2000: 22 238; 2001-2002: 43 350; 20032004: 30 479; 2005-2006: 36 802. Percebe-se que houve um decréscimo do volume da participação em 1999-2000, mas logo ela voltou a crescer. Há que se assinalar que Belo Horizonte é a mais populosa das quatro metrópoles estudadas, portanto, espera-se ela apresente números absolutos maiores.

Em Recife, é possível que o OP tenha encontrado um equilíbrio entre dimensões que, na operação de instituições participativas, por vezes aparecem contrapostas: participação em grande número versus discussão com deliberação $\mathrm{e}$ interações face-a-face, que permitem o agir comunicativo presidir processos decisórios. De alguma forma, a experiência pernambucana tem buscado contemplar aspectos quali e quantitativos da participação como teorizado nas seções anteriores e apresentam números que fariam desse OP, segundo o poder Executivo municipal, o maior do Brasil, o que de fato é verdade, conforme dizem os números: 2001: 26 257; 2002: 41 891; 2003: 42 426; 2004: 33 592; 2005: 46 892; 2006: 38 986; 2007: 45 652; 2008: 38 605. Cifras que, inclusive, ultrapassam as quantias de Belo Horizonte, cidade com população significativamente maior.

Não existem muitos dados que permitam trazer informações mais precisas e que sejam capazes de especificar o grau da participação alcançada nas APs de Curitiba. Segundo a PMC (CURITIBA, 2011), cerca de 5000 mil pessoas participaram das audiências em 2011, número expressivamente inferior aos das demais cidades pesquisadas. Nossas observações trazem, entretanto, indícios de que as camadas pobres da cidade participam e ocupam esse espaço, ganhando visibilidade pública, justamente aqueles setores que mais foram marginalizados pelas políticas de cunho tecnocrata das décadas anteriores.

Em todas as cidades estudadas, milhares de pessoas tomam parte dos arranjos participativos. Os índices de participação variam significativamente, no entanto, sendo comparativamente baixo em Curitiba, um pouco mais alto em Porto Alegre e atingindo os dois dígitos em Belo Horizonte e Recife. Para chegar a essas análises, estabelecemos um índice de particpação (IP), medido pela quantidade de participantes para cada 
grupo de mil habitantes, no último ano com dados disponíveis (Tabela 4). A efetividade da ocupação do espaço público varia bastante de uma cidade para outra.
Todavia, ao menos para as quatro cidades estudadas, é possível depreender que os orçamentos participativos têm atraído parcelas maiores das populações, mesmo com a diminuição dos números em Porto Alegre.

TABELA 4 - ÍNDICES DE PARTICIPAÇÃO (IP) NAS INSTITUIÇÕES PARTICIPATIVAS DAS CAPITAIS PESQUISADAS (N DE PARTICIPANTES POR MIL HAB.)

\begin{tabular}{|l|c|c|c|}
\hline CIDADE (INSTITUIÇÃO) & POPULAÇÃO & PARTICIPANTES & IP \\
\hline Porto Alegre (OP) & 1440940 & 11097 & 7,70 \\
Belo Horizonte (OP) & 2399920 & 36802 & 15,33 \\
Recife (OP) & 1549980 & 38605 & 24,91 \\
Curitiba (AP) & 1746896 & 5000 & 2,86 \\
\hline
\end{tabular}

FONTE: os autores, a partir de Belo Horizonte (2007; 2011), Curitiba (2009; 2011), Porto Alegre (2010), Brasil. Datasus (2011) e Recife (2011).

Ao examinar a variável "participação", pela "ocupação efetiva do espaço participativo", é possível inferir que esta se faz fortemente presente em Belo Horizonte e Recife. O desempenho inferior do OP de Porto Alegre em relação a seus congêneres pode estar associado às mudanças no desenho institucional, operadas quando um grupo político oposto ao que implantou o arranjo participativo conquistou o poder Executivo municipal. Comparativamente, em Curitiba, parcela ínfima da população freqüenta as APs. Várias podem ser as razões: a experiência curitibana é relativamente recente e, frise-se, não comporta uma deliberação efetiva. Suas resultantes aparentemente influenciam o poder público de maneira difusa, de difícil reconhecimento imediato pela população, diferentemente do que ocorre nos OPs. Uma síntese do comportamento das variáveis que compõem a dimensão "Política" pode ser encontrada na Tabela 5.

TABELA 5-COMPORTAMENTO DAS VARIÁVEIS DA DIMENSÃO "POLÍTICA"

\begin{tabular}{|c|c|c|c|c|c|}
\hline \multirow[b]{2}{*}{ VARIÁVEL } & \multirow{2}{*}{$\begin{array}{l}\text { AUSÊNCIA (0), PRESENÇA FRACA } \\
\text { (1), PRESENÇA FORTE (2) DE: }\end{array}$} & \multicolumn{4}{|c|}{ CIDADE } \\
\hline & & $\begin{array}{l}\text { PORTO } \\
\text { ALEGRE }\end{array}$ & $\begin{array}{c}\text { BELO } \\
\text { HORIZONTE }\end{array}$ & RECIFE & CURITIBA \\
\hline Representação & Públicos múltiplos & 2 & 1 & 2 & 1 \\
\hline Participação & $\begin{array}{l}\text { Ocupação efetiva do espaço } \\
\text { participativo }\end{array}$ & 1 & 2 & 2 & 0 \\
\hline Total de pontos & áximo 4) & 3 & 3 & 4 & 1 \\
\hline
\end{tabular}

FONTE: os autores, a partir de Belo Horizonte (2007; 2011), Curitiba (2009; 2011), Porto Alegre (2010) e Recife (2011).

\section{III.4. Accountability}

\section{III.4.1. Transparência}

O OP de Porto Alegre favorece a accountability no tocante à transparência dos atos da administração municipal na medida em que os cidadãos passam a ter direito de tomar decisões sobre tendências gerais e obras públicas específicas, acedendo informação técnica e financeira vital (WAMPLER, 2004). Cria-se a perspectiva de redução da assimetria de informação e, ato contínuo, a peça orçamentária 
aproxima-se do efetivamente executado, em comparação com a verdadeira "caixa preta" que costuma ser o orçamento público para a sociedade em geral. O COP, como instrumento de fiscalização e monitoramento, ganha destaque.

No OP belo-horizontino não é diferente. São vários os mecanismos que conferem a ele uma forte transparência, que permitem o exercício do controle do governo municipal pelos cidadãos. $\mathrm{O}$ RI do OP é lido e aprovado nas assembléias da primeira rodada, bem como a divulgação do encaminhamento das demandas dos OPs dos anos anteriores. Também é público o valor do orçamento a ser decidido, tanto em termos globais quanto as frações deste destinado para cada Unidade de Planejamento. Como em Porto Alegre, há um mecanismo de monitoramento das decisões do OP, a Comforça, que "constitui a resposta política do OP a uma tendência generalizada nas administrações locais no Brasil de insulamento das burocracias técnicas. Com o monitoramento, a população consegue influenciar na execução de suas decisões" (AVRITZER, 2002b, p. 27).

O OP de Recife oferece, de modo semelhante, ampla divulgação dos resultados, tanto no que concerne à deliberação quanto no tocante aos investimentos nas prioridades elencadas pelos cidadãos e na existência do COP, sendo possível identificar a correspondência entre o que se delibera e os investimentos realizados (SILVA, 2003).

Em Curitiba, alguma transparência residiria na explicação pedagógica sobre como se constitui a agenda orçamentária municipal e a forma como os investimentos dos anos anteriores foram aplicados. Os técnicos da prefeitura não economizam tempo e nem explicações, que por vezes tornam-se extremamente densas e de difícil compreensão. Tal fato compromete a própria transparência, uma vez que a linguagem dos burocratas é, por vezes, ininteligível para o cidadão. Não se percebe preocupação em tornar essa prestação de contas mais clara, sucinta e de fácil entendimento. As falas dos técnicos e documentos publicados no site da PMC repetem menções genéricas a um percentual de cerca de $8 \%$ para investimentos e que a alocação destes seria fruto das demandas e prioridades identificadas nas APs e demais processos de consulta. No entanto, não há documentos acessíveis ao cidadão que mostrem o vínculo entre o que foi discutido nas
APs e coletado como preferências dos cidadãos e o que foi realmente executado.

A presença de "prestação de contas", medida da variável "transparência", é forte nos três OPs pesquisados, dado que os cidadãos têm acesso à prestação de contas relacionadas aos processos participativos. Nesse sentido específico, é válida a afirmação de que uma efetiva prestação de contas está ausente das APs curitibanas.

\section{III.4.2. Responsividade}

EmPorto Alegre a transparência opera em linha com a responsividade dos agentes político-estatais, em face da submissão de parte, ainda que tímida, das políticas municipais à deliberação dos participantes no OP. O seu Regimento Interno prevê dispositivos que obrigam a gestão municipal a prestar contas e a honrar as decisões emanadas daquela instância. À população, torna-se significativamente mais fácil entender o método orçamentário e, conseqüentemente, formular e apresentar seus inputs societais, possibilitando que estratos populacionais historicamente alijados das políticas públicas tenham suas demandas consideradas e atendidas pelo poder público.

Na capital mineira, os citados IQVU e o critério de Áreas Prioritárias induzem as áreas mais necessitadas a ter primazia no atendimento das demandas eleitas pelos próprios cidadãos. A introdução de instrumentos como esses, ainda que informados pela razão técnica, leva ao incremento da responsividade dos governos, especialmente no tocante às necessidades dos grupos sociais mais vulneráveis (PIRES, 2009).

O OP de Recife tem permitido a absorção das demandas societais, ainda que a parcela objeto de deliberação dos cidadãos represente percentual acanhado do orçamento global. A própria dinâmica de discussão e deliberação, de que participa camada representativa da população, do modo como ela ocorre, permite ao cidadão comum vocalizar e ter consideradas suas demandas, não apenas no âmbito do OP, mas no desenho do conjunto das políticas públicas no que elas têm de discricionárias. As sucessivas vitórias eleitorais do grupo à frente do poder Executivo municipal desde 2001 sinalizam, ainda, que o OP no Recife tem sido utilizado como estratégia bem sucedida de identificação e atendimento das demandas, tornando a prefeitura municipal e seus agentes mais responsivos perante população da cidade. $\mathrm{O}$ 
mesmo vale para Porto Alegre e Belo Horizonte.

As APs de Curitiba são freqüentadas pelas camadas carentes da cidade, que de algum modo adquirem visibilidade pública, essencial a seu empoderamento. Possivelmente, esses grupos veem nas audiências uma das poucas senão a única oportunidade para investir seus parcos recursos políticos e obter retornos. Os limites residem na resistência à partilha de poder por parte da prefeitura, fato que se mostra na dinâmica interna dos encontros. A ausência de uma estrutura decisória compromete a responsividade, uma vez que o controle sobre o Estado torna-se quase informal, não havendo mecanismos que vinculem institucionalmente o produto das APs à execução efetiva do orçamento.

A análise da variável em apreço revela com nitidez as diferenças entre os OPs e as APs de
Curitiba. Aqueles geram governos com mais "responsividade", variável ora medida pela "correspondência entre inputs e outputs", fortemente presente em Porto Alegre, Belo Horizonte e Recife. Essa correspondência não chega a ausentar-se das APs curitibanas, justamente porque as audiências públicas de alguma forma colocam população e governo frente a frente em uma arena pública, senão deliberativa, ao menos de pressão para que as demandas sejam consideradas no momento de aplicação dos recursos orçamentários.

O comportamento das variáveis relacionadas à accountability está resumido na Tabela 6 , abaixo. Os índices atingidos pelas cidades com OP permitem-nos afirmar que essa dimensão é aquela na qual esse arranjo participativo cumpre os requisitos da democracia deliberativa de maneira integral.

TABELA 6 - COMPORTAMENTO DAS VARIÁVEIS DA DIMENSÃO "ACCOUNTABILITY"

\begin{tabular}{|l|c|c|c|c|c|}
\hline \multirow{2}{*}{ VARIÁvel } & AUSÊNCIA (0), PRESENÇA & \multicolumn{5}{|c|}{ CIDADE } \\
\cline { 3 - 7 } & $\begin{array}{c}\text { FRACA (1), PRESENÇA } \\
\text { FORTE (2) DE: }\end{array}$ & $\begin{array}{c}\text { PORTO } \\
\text { ALEGRE }\end{array}$ & $\begin{array}{c}\text { BELO } \\
\text { HORIZONTE }\end{array}$ & RECIFE & CURITIBA \\
\hline Transparência & Prestação de contas & 2 & 2 & 2 & 0 \\
Responsividade & $\begin{array}{c}\text { Correspondência entre } \\
\text { inputs e outputs }\end{array}$ & 2 & 2 & 2 & 1 \\
Total de pontos (máximo 4) & & 4 & 4 & 4 & 1 \\
\hline
\end{tabular}

FONTE: os autores, a partir de Belo Horizonte (2007; 2011), Curitiba (2009; 2011), Porto Alegre (2010) e Recife (2011).

\section{CONCLUSÕES}

Estudos comparativos sobre a participação social no orçamento público no Brasil confrontam, em geral, diferentes orçamentos participativos. Propusemos aqui um ponto de partida alternativo: cotejar experiências bastante diferenciadas na origem, estrutura e nos grupos que a implantaram. É o caso dos OPs de Porto Alegre, Belo Horizonte e Recife vis-à-vis as APs de Curitiba.

O fulcro das análises são pressupostos centrais da democracia deliberativa, presentes desde a sua elaboração habermasiana original, que podem ser sumarizados da seguinte forma: a legitimidade das decisões de interesse coletivo resulta da participação autônoma dos cidadãos por elas afetados, em esferas públicas ampliadas, com processos de deliberação mediados pelo diálogo livre, presidido pela razão comunicativa em vez da razão instrumental sistêmica, relacionada ao poder econômico e ao poder político. Para a sua operacionalização, adaptamos as dimensões propostas por Faria e Ribeiro (2010), avaliadas pela presença-ausência de variáveis que atendem os referidos pressupostos. Nessas considerações finais, sintetizamos os resultados para cada uma das dimensões.

No tocante à dimensão "desenho institucional", concluímos que nas audiências públicas orçamentárias de Curitiba os cidadãos não definem as regras de funcionamento, em contraste com o observado nas outras três cidades. Todas as instituições, de modo direto ou indireto, acolhem os cidadãos em suas instâncias. As APs curitibanas preveem, no entanto, participação meramente consultiva. Belo Horizonte oferece incentivos evidentes às comunidades que tomam parte do 
OP e Recife proporciona mais de uma instância de participação direta da população - o que não ocorre em Porto Alegre desde 2009.

Quanto às discussões, as possibilidades de debate aberto, com réplicas e tréplicas, estão mais presentes nos desenhos institucionais dos OPs de Belo Horizonte (destacando-se, aqui, a Caravana das Prioridades) e Recife. Os cidadãos podemfalar nas APs de Curitiba, mas além de o tempo ser bastante limitado, não há deliberação, diferentemente do que acontece nos OPs, ainda que a proporção discutida dos orçamentos municipais seja diminuta em todas as cidades, nunca excedendo a décima parte. Ademais, o poder decisório é restringido pela dimensão técnico-burocrática em Belo Horizonte.

Na dimensão "contexto", Recife e Belo Horizonte destacam-se pelo vigoroso associativismo, considerando o número de associações e a população das cidades, devendose, no entanto, sopesar o caráter personalista do associativismo belo-horizontino, indicado por Avritzer (2002b). Porto Alegre apresenta um índice surpreendentemente modesto quando seus números são confrontados ao que costuma afirmar a literatura e certo senso comum generalizado sobre a organização da sociedade civil na capital gaúcha.

A implantação das APs foi um processo nitidamente top down em Curitiba, imposto pelo aparato burocrático e obedecendo a constrangimentos legais. Conseqüentemente, dirigiu-a uma racionalidade instrumental. Recife e Porto Alegre, por seu turno, constituíram seus OPs a partir das bases da sociedade civil, na esteira da redemocratização do país. Belo Horizonte encontra-se no meio do caminho devido a um importante viés burocrático.

Do ponto de vista da dimensão "política", todos os desenhos abrigam a representação dos mais diversos estratos da sociedade, inclusive os mais carentes. Todavia, Porto Alegre e Recife, por possuírem assembléias temáticas, aumentam o leque de alternativas, tornando possível a presença de públicos múltiplos e mais heterogêneos em suas instâncias, mesmo os contrapúblicos subalternos de que fala Fraser (1992). Quanto à participação, é nítido o declínio de Porto Alegre nos últimos anos, em especial após a extinção da segunda rodada de assembléias. É necessário ver com certa reserva os, à primeira vista, significativos números de participantes em Belo Horizonte, devido a seu processo ser bianual e sua população, maior. Os curitibanos aparentemente não "descobriram" as audiências públicas, pois o percentual de participantes é, de longe, o menor. $\mathrm{O}$ destaque fica para Recife, com seu alto nível de participação, o maior entre as cidades pesquisadas, em termos relativos e absolutos.

Em relação à dimensão "accountability", a prestação de contas em Curitiba é obstruída pelos recursos comunicacionais excessivamente técnicos, por vezes ininteligíveis, e a ausência de dados públicos que demonstrem a vinculação entre as prioridades e demandas elencadas pela população e a execução orçamentária. Nos demais casos, a existência de um mecanismo de monitoramento (Comforça, em Belo Horizonte, e COPs, em Porto Alegre e Recife) torna a prestação de contas mais efetiva devido à fiscalização que se impõe sobre os poderes executivos municipais. Como consequiência, os OPs geram governos mais responsivos, inclusive com evidentes inversões de prioridades em direção às áreas mais vulneráveis das cidades. O fenômeno não é claramente observável em Curitiba, mercê da carência de dados e informações que comprovem a correspondência entre inputs e outputs. É possível supor, no entanto, que as camadas mais carentes vêm paulatinamente ganhando visibilidade pública com as APs, notadamente perante os sujeitos que decidem o destino dos investimentos na capital paranaense. Pesquisas futuras poderão demonstrar em que medida isso se converteu em melhorias para essas pessoas.

A Tabela 7, abaixo, traz as pontuações obtidas por cada uma das instituições participativas analisadas, cuja somatória perfaz seus Índices de Democracia Deliberativa e, conforme postulamos, sua aderência maior ou menor aos pressupostos da democracia deliberativa. 
TABELA 7 - ÍNDICES DE DEMOCRACIA DELIBERATIVA (IDD)

\begin{tabular}{|l|c|c|c|c|}
\hline \multirow{2}{*}{ DIMENSÃo } & \multicolumn{4}{|c|}{ CIDADE (INSTITUIÇÃO) } \\
\cline { 2 - 6 } & $\begin{array}{c}\text { PORTO ALEGRE } \\
\text { (OP) }\end{array}$ & $\begin{array}{c}\text { BELO HORIZONTE } \\
\text { (OP) }\end{array}$ & $\begin{array}{c}\text { RECIFE } \\
\text { (OP) }\end{array}$ & $\begin{array}{c}\text { CURITIBA } \\
\text { (APS) }\end{array}$ \\
\hline Desenho institucional & 5 & 7 & 6 & 2 \\
Contexto & 3 & 3 & 4 & 0 \\
Política & 3 & 3 & 4 & 1 \\
Accountability & 4 & 4 & 4 & 1 \\
IDD & 15 & 17 & 18 & 4 \\
\hline
\end{tabular}

FONTE: os autores.

Recife e seu OP apresentam o maior IDD, Curitiba, o menor, e Belo Horizonte e Porto Alegre obtêm médias elevadas, com um desempenho levemente superior da primeira. É importante ressaltar que a escala não representa um tipo ideal que existe somente como constructo intelectual a partir de abstrações teóricas. A escala representa, antes, um tipo ideal plausível e possível, construído a partir de experiências concretas de participação social. É por esse motivo que as três capitais com OP apresentaram pontuação mais elevada, e, no caso do Recife, um índice muito próximo do máximo.

Reconhecendo o caráter arbitrário e tentativo da proposta da pesquisa apresentada neste artigo, concluímos que a experiência da capital pernambucana tem-se mostrado mais próxima do que preconiza a teoria deliberativa, seja em seus aspectos formais e procedimentais, seja em seu funcionamento concreto com a participação de sujeitos de carne e osso.

Foge aos nossos objetivos afirmar que um ou outro desses arranjos seja mais ou menos eficaz ou eficiente num sentido amplo, especialmente porque os grupos que os implantaram e suas respectivas intencionalidades divergiam consideravelmente, mormente quando se compara o conjunto dos OPs com as APs de Curitiba. Em alguns aspectos todos são, porém, bastante congruentes, revelando: (i) baixo percentual do orçamento público colocado em deliberação; (ii) predominância do poder Executivo municipal, que toma a dianteira dos processos; (iii) um método assembleísta regional de reuniões públicas; (iv) representatividade e participação dos setores mais carentes das cidades e $(v)$ responsividade da gestão pública para com a sociedade, incrementando a accountability.
Pouco judicioso seria considerar as APs curitibanas meros espaços de aclamação pública, a despeito de Curitiba ser a cidade a apresentar menos elementos constitutivos da democracia deliberativa. Disputas estão presentes e podem ser assinaladas como um elemento com alto potencial de contribuição para a qualidade da democracia em nível local. A par de suas limitações, as APs têm a normatividade de um espaço público que possibilita pressões externas por parte da população organizada. A sua existência recente já é em si um complicador do jogo político e, a despeito dos limites, a constituição de uma estrutura de oportunidades comportaria deliberações e tematizações mais qualificadas sobre a agenda política.

Os casos estudados sinalizam, principalmente, a influência, sobre os formatos participativos, das orientações ideológicas ou de princípios normativos dos grupos que implantam e, sobretudo, conduzem os processos. Os dados coligidos indicam que experiências nascidas de bases comunitárias e inauguradas por grupos de esquerda são mais bem sucedidas em promover uma participação efetiva e autônoma, porque este é um objetivo dos sujeitos envolvidos, ao menos em suas declarações públicas, conformando também a estratégia eleitoral. É o caso dos OPs. Mais importante ainda é o comprometimento governamental e partidário para com o prosseguimento das experiências. Porto Alegre exibiu perda de sua dinâmica participativa quando trocou o grupo dirigente, uma vez que as alterações nas regras postas em prática não lograram sucesso se a meta era aumentar a participação. O Índice de Democracia Deliberativa dessa cidade, inferior ao das duas outras com OP e que tiveram continuidade no comando dos poderes executivos, assinala uma tendência. 
Seguindo a mesma linha de raciocínio, quando se trata de um processo de cima para baixo, estabelecido por um grupo político tradicionalmente autoritário e respondendo mais a pressões institucionais do que à meta de democratizar o espaço público, limites mais sensíveis colocam-se, como parece acontecer em Curitiba. Nesse caso, o tímido desempenho em face dos pressupostos da democracia deliberativa talvez não seja um efeito imprevisto e indesejável, mas sim decorrência dos objetivos estratégicos dos sujeitos que hegemonizam o jogo político.

A burocracia técnica tem um grande peso sobre os desenhos participativos, afetando as regras que governam as interações entre os agentes. Curitiba e Belo Horizonte são exemplos claros. A primeira se sobressai pela colonização da esfera pública mediante a primazia da racionalidade instrumental sobre a comunicativa. A segunda procura encontrar um equilíbrio entre as duas razões com vistas a corrigir desigualdades invertendo prioridades de investimento. Nesse ponto, persiste o dilema habermasiano sobre a capacidade dos processos dialógicos por si só garantirem a formação da vontade e gerar a melhor decisão possível por meio de acordos públicos consensuais.

Por fim, em qualquer dos casos, pouco premeditado é o papel exercido pela população que, tais quais os russos de Garrincha, pode não agir conforme o combinado, rasgando o script, exercendo pressão, criticando abertamente a administração municipal, e de uma forma ou de outra, conseguindo ganhar visibilidade e ter suas demandas respondidas pelos agentes públicos. O empoderamento e a ampliação da accountability parecem evidentes em todas as experiências, em uma comprovação de que estruturas de oportunidade política são essenciais para a qualidade da democracia, considerando os pressupostos normativos adotados aqui e com todos os limites apontados por uma vastíssima literatura.

Mais do que conclusões, o presente estágio de nossas investigações sugere diversas aberturas para a sua continuidade. Um exemplo é a possibilidade de incorporar, de maneira mais sistemática, os elementos críticos da teoria, perscrutando como os diferentes estratos populacionais comportam-se durante os procedimentos, se suas diferenças refletem-se nos resultados obtidos. Trata-se, nesse caso, de uma análise densa da participação, de seu conteúdo e, principalmente, de sua qualidade em relação à democratização da esfera pública.

Outra possibilidade, mais complexa, decorre das próprias barreiras encontradas na realização desta investigação. Pesquisas empíricas sobre democracia deliberativa são raras no Brasil, estando quase ausentes das bases bibliográficas mais consagradas. Praticamente inexistem dados, sobretudo quantitativos, que permitam comparações mais precisas entre instituições participativas do país à luz da teoria em apreço. Parte significativa da produção sobre o tema são estudos de caso, com procedimentos específicos. Depara-se, também, com expressiva dificuldade em encontrar séries históricas consistentes. Algumas pesquisas bastante interessantes sofrem interrupções, às vezes definitivas. Tal quadro sinaliza a pertinência de que os pesquisadores sobre o tema unam-se para realizar estudos em escala nacional, com procedimentos padronizados e de caráter longitudinal, visando à constituição de um repositório robusto para o desenvolvimento de futuras investigações.

Enfrentar esses e outros desafios teóricos e práticos remete à necessidade de aperfeiçoamento dos instrumentos de coleta e análise de dados. $\mathrm{O}$ ganho esperado é uma contribuição efetiva para o extenso campo de pesquisa empírica sobre a democracia e sua ampliação tendo como guia a sua vertente deliberativa.

Rodrigo Rossi Horochovski (rodrigorh@ufpr.br) é Doutor em Sociologia Política pela Universidade Federal de Santa Catarina (UFSC) e Professor de Ciência Política na Universidade Federal do Paraná (UFPR).

Augusto Junior Clemente (augustoclemente@ymail.com) é Doutorando em Ciência Política pela Universidade Federal do Rio Grande do Sul (Ufrgs). 


\section{REFERÊNCIAS BIBLIOGRÁFICAS}

AVRITZER, L. 1996. A moralidade da democracia: ensaios em teoria habermasiana e teoria democrática. Belo Horizonte: UFMG.

2002a. Democracy and the Public Space in Latin America. New York: Princeton University.

2002b. O orçamento participativo: as experiências de Porto Alegre e Belo Horizonte. In: DAGNINO, E. (org.). Sociedade civil e espaços públicos no Brasil. São Paulo: Paz e Terra.

2006. Reforma política e participação no Brasil. In: AVRITZER, L. \& ANASTASIA, F. (orgs.). Reforma política no Brasil. Belo Horizonte: UFMG.

2007. Sociedade civil, instituições participativas e representação: da autorização à legitimidade da ação. Dados, Rio de Janeiro, v. 50, n. 3, p. 443-464. Disponível em: http:// www.scielo. br/pdf/dados/v50n3/0 1.pdf. Acesso em: 12.nov.2012.

AVRITZER, L.; MOTA, A. C.; CUNHA, E. S. M.; MESQUITA, E. C.; COELHO, D. B.; TOMAS, M. C.; PIRES, R. R. C. \& RAMALHO, T. 2007. Relatório da pesquisa participação e distribuição nas políticas públicas do Nordeste. Belo Horizonte: Projeto Democracia Participativa.

AZEVEDO, S. \& ANASTASIA, F. 2002. Governança, "accountability" e responsividade. Revista de Economia Política, São Paulo, v. 22, n. 1, p. 79-97, jan.-mar. Disponível em: http://www.empreende.org.br/pdf/ Programas\%20e\%20Pol\%C3\%ADticas\% 20 Sociais/Governan\% C3\% A 7a, \% 20 accountability\%20e\%20responsividade.pdf. Acesso em: 12.nov.2012.

AZOLIN, A. J. 2011. Participação política e nova gestão pública: a gestão da participação no orçamento público de Curitiba. Curitiba. Dissertação (Mestrado em Ciência Política). Universidade Federal do Paraná.

BENHABIB, S. 1992. Situating the Self: Gender, Community and Postmodernism in Contemporary Ethics. New York: Routledge.

2009. Rumo a um modelo deliberativo de legitimidade democrática. In: MARQUES, A.
C. S. (org.). A deliberação pública e suas dimensões sociais, políticas e comunicativas: textos fundamentais. Belo Horizonte: Autêntica.

BOSCHI, R. R. 1987. A arte da associação: política de base e democracia no Brasil. São Paulo: Vértice.

BRAGA, M. C. A. \& BRAGA, S. H. F. 2008. Gestão democrática no Recife: o uso do orçamento participativo como parâmetro de análise. Humanae, Recife, v. 1, n. 2, p. 37-54, dez. Disponível em: http://www.humanae. esuda.com.br/index.php/humanae/article/ download/57/39. Acesso em: 12.nov.2012.

CHAMBERS, S. 2009. A teoria democrática deliberativa. In: MARQUES, A. C. S. (org.). A deliberação pública e suas dimensões sociais, políticas e comunicativas: textos fundamentais. Belo Horizonte: Autêntica.

CLEMENTE, A. J. 2008. Gestão pública descentralizada e participação política: a relação das associações de moradores do bairro Batel e da Vila Pantanal com as administrações regionais e audiências públicas realizadas pela Prefeitura Municipal de Curitiba - 2005-2006. Revista Intersaberes, Curitiba, v. 3, n. 6, p. 204-229, jul.-dez.

2011. Democracia deliberativa e esfera pública: a experiência das audiências públicas de Curitiba. Curitiba. Dissertação (Mestrado em Ciência Política). Universidade Federal do Paraná.

COHEN, J. \& ROGERS, J. 1995. Associations and Democracy. In: WRIGHT, E. O. (ed.). The Real Utopias Project. V. 1. New York: Verso.

COHEN, J. \& SABEL, C. 1997. DirectlyDeliberative Polyarchy. European Law Journal, Oxford, v. 3, n. 4, p. 313-342, Dec.

COSTA, D. M. D. 2010. Vinte anos de orçamento participativo: análise das experiências em municípios brasileiros. Cadernos Gestão Pública e Cidadania, São Paulo, v. 15, n. 56, p. 8-28. Disponível em: http://biblioteca digital.fgv.br/ojs/index.php/cgpc/article/view/ 3190/2093. Acesso em: 12.nov.2012.

DAGNINO, E. 2002. Sociedade civil e espaços públicos no Brasil. São Paulo: Paz e Terra. 
DIAS, M. R. 2000. Na encruzilhada da teoria democrática: efeitos do orçamento participativo sobre a Câmara Municipal de Porto Alegre. Rio de Janeiro. Tese (Doutorado em Ciência Política). Instituto Universitário de Pesquisas do Rio de Janeiro.

DOIMO, A. M. 1995. A vez e a voz do popular: movimentos sociais e participação política no Brasil pós-70. Rio de Janeiro: Relume Dumará.

DRYZEK, J. S. 2000. Deliberative Democracy and Beyond. Oxford: Oxford University.

FARIA, C. F. 2006. Fóruns participativos, controle democrático e a qualidade da democracia no Rio Grande do Sul: a experiência do governo Olívio Dutra (1999-2002). Opinião Pública, v. 12, n. 2, p. 378-406, nov. Disponível em: http://www.scielo.br/pdf/op/ v12n2/07.pdf. Acesso em: 12.nov.2012.

2010. Do ideal ao real: as conseqüências das mudanças conceituais na teoria da democracia deliberativa. Trabalho apresentado no $7^{\circ}$ Encontro Nacional da Associação Brasileira de Ciência Política, realizado em Recife, de 4 a 7 de agosto. Disponível em: http://cienciapolitica.servicos.ws/abcp2010/ arquivos/27_7_2010_14_43_4.pdf. Acesso em: 11.nov.2012

FARIA, C. F. \& RIBEIRO, U. C. 2010. Entre o legal e o real: o que dizem as variáveis institucionais sobre os Conselhos de Políticas Públicas. In: AVRITZER, L. (org.). A dinâmica da participação local no Brasil. São Paulo: Cortez.

FUNG, C. F. \& WRIGHT, E. O. 2003. Deepening Democracy: Institucional Innovations in Empowered Participatory Governance. New York: Verso.

FRASER, N. 1992. Rethinking the Public Sphere: a contribution to the Critique of Actually Existing Democracy. In: CALHOUN, C. (ed.). Habermas and the Public Sphere. Cambridge (MA): MIT.

GOHN, M. G. 2004. Empoderamento e participação da comunidade em políticas sociais. Saúde e Sociedade, São Paulo, v. 13, n. 2, p. 20-31, maio-ago. Disponível em: http:/ /www.scielo.br/pdf/sausoc/v13n2/03.pdf. Acesso em: 8.nov.2012.
GUGLIANO, A. A. 2009. A participação popular fechou as portas? Limites da gestão participativa em Porto Alegre. Trabalho apresentado no $14^{\circ}$ Congresso Brasileiro de Sociologia, realizado no Rio de Janeiro, de 28 a 31 de julho. Disponível em: http:// www.sbsociologia.com.br/portal/ index.php?option $=$ com_docman\&task= doc_download\&gid=3246\&Itemid=171. Acesso em: 12.nov.2012.

HABERMAS, J. 1976. Técnica e ciência enquanto “ideologia”. Col. "Os pensadores”. São Paulo: Abril Cultural.

1995. Três modelos normativos de democracia. Lua Nova, São Paulo, n. 36, p. 39-53. Disponível em: http://www.scielo.br/pdf/ln/ n36/a03n36.pdf. Acesso em: 12.nov.2012.

2000. O discurso filosófico da modernida$d e$ : doze lições. São Paulo: M. Fontes.

2003a. Consciência moral e agir comunicativo. $2^{\mathrm{a}}$ ed. Rio de Janeiro: Tempo Brasileiro.

2003b. Mudança estrutural da esfera pública: investigações quanto a uma categoria da sociedade burguesa. $2^{\mathrm{a}}$ ed. Rio de Janeiro: Tempo Brasileiro.

JACOBI, P. R. 1996. Ampliação da cidadania e participação: desafios na democratização da relação poder público-sociedade civil no Brasil. São Paulo. Tese (Livre-Docência em Educação). Universidade de São Paulo.

LÜCHMANN, L. H. H. 2002. Possibilidades $e$ limites da democracia deliberativa: a experiência do orçamento participativo de Porto Alegre. Campinas. Tese (Doutorado em Ciência Política). Universidade Estadual de Campinas.

MACPHERSON, C. B. 1982. La democracia liberal y su época. Madrid: Alianza.

MANSBRIDGE, J. 1999. Everyday Talk in the Deliberative System. In: MACEDO, S. (ed.). Deliberative Politics: Essays on Democracy and Disagreement. New York: Oxford University.

2007. Deliberative Democracy or Democratic Deliberation? In: ROSENBERG, S. (ed.) Deliberation, Participation and Democracy: 
Can the People Govern? Basingstoke: Palgrave Macmillan.

MANSBRIDGE, J.; BOHMAN, J.; CHAMBERS, S.; ESTLUNG, D.; FØLLESDAL, A.; FUNG, A.; LAFONT, C.; MANIN, B. \& MARTí, J. L. 2010. The Place of Self-Interest and the Role of Power in Deliberative Democracy. Journal of Political Philosophy, Oxford, v. 18, n. 1, p. 64-100, Mar.

MATTHAEUS, H. 1995. Urban Management, Participation and the Poor in Porto Alegrel Brazil. Birmingham: Institute of International Development.

MIGUEL, L. F. 2005. Teoria democrática atual: esboço de mapeamento. BIB, São Paulo, n. 59 , p. $5-42$.

MOUFFE, C. 2005. Por um modelo agonístico de democracia. Revista de Sociologia e Política, Curitiba, n. 25, p. 11-23, nov. Disponível em: http://www.scielo.br/pdf/rsocp/n25/ 31108.pdf. Acesso em: 12.nov.2012.

NAVARRO, Z. 1999. Democracia e controle social de fundos públicos: o caso do orçamento participativo de Porto Alegre (Brasil). In: PEREIRA, L. C. B. \& GRAU, N. C. (orgs.). O público não estatal na reforma do Estado. Rio de Janeiro: Fundação Getúlio Vargas.

NAZARENO, L. 2005. Redes sociais e coalizão de governo em Curitiba 1985-2004. São Paulo. Dissertação (Mestrado em Ciência Política). Universidade de São Paulo.

NYLEN, W. 2000. The Making of Loyal Opposition: the Worker's Party (PT) and the Consolidation of Democracy in Brazil. In: KINGSTONE, P. \& POWER, T. J. (eds.). Democratic Brazil: Actors, Institutions, and Processes. Pittsburgh: University of Pittsburgh.

OFFE, C. 1989. Capitalismo desorganizado. São Paulo: Brasiliense.

PIRES, R. R. C. 2009. Participação cidadã e planejamento governamental: um equilíbrio possível? Reflexões sobre o orçamento participativo de Belo Horizonte. Pensar BH/ Política Social, Belo Horizonte, n. 24, p. 1013, nov.

SADER, E. 1995. Quando novos personagens entraram em cena: experiências e lutas dos trabalhadores da Grande São Paulo 1970-1980. $2^{\mathrm{a}}$ ed. Rio de Janeiro: Paz e Terra.

SANTOS, B. S. 1998. Participatory Budgeting in Porto Alegre: Toward a Redistributive Democracy. Politics \& Society, Thousand Oaks, v. 26, n. 4, p. 461-510, Dec.

2003. Democratizar a democracia: os caminhos da democracia participativa. Rio de Janeiro: Civilização Brasileira.

SCHERER-WARREN, I. 1996. Redes de movimentos sociais. $2^{\mathrm{a}}$ ed. São Paulo: Loyola.

SETZLER, M. 2000. Democratizing Urban Brazil: Institutional Legacies and Determinants of Accountability in Local Elections and Legislatures. Trabalho apresentado no $22^{\circ}$ Congresso Internacional da Latin American Studies Association, realizado em Miami, de 16 a 18 de março. Digit.

SHAPIRO, I. 2005. The State of Democratic Theory. Princeton: Princeton University.

SILVA, T. 2003. Da participação que temos à que queremos: o processo do orçamento participativo na cidade do Recife. In: AVRITZER, L. \& NAVARRO, Z. (orgs.). A inovação democrática no Brasil: o orçamento participativo. São Paulo: Cortez.

SOUZA, C. 2001. Construção e consolidação de instituições democráticas: papel do orçamento participativo. São Paulo em Perspectiva, São Paulo, v. 15, n. 4, p. 84-97, out.-dez. Disponível em: http://www.scielo.br/pdf/spp/ v15n4/10375.pdf. Acesso em: 11.nov.2012.

SOUZA, N. R. 1999. Planejamento urbano, saber e poder: o governo do espaço e da população de Curitiba. São Paulo. Tese (Doutorado em Sociologia). Universidade de São Paulo.

2003. Democracia participativa e política pública no contexto neoliberal: o caso do Conselho da Criança e do Adolescente de Curitiba-BR. Trabalho apresentado no $36^{\circ}$ Encontro Anual da Associação Nacional de PósGraduação e Pesquisa em Ciências Sociais, realizado em Caxambu (MG), de 21 a 25 de outubro. Digit.

VISCARRA, S. P. 2010. Cultura política, participação e bem-estar no Rio Grande do Sul. Trabalho apresentado no $7^{\circ}$ Encontro da Associação Brasileira de Ciência Política, 
realizado em Recife, de 4 a 7 de agosto. Disponível em: http://cienciapolitica.servicos. ws/abcp2010/arquivos 11_7_2010_22_39_ 18.pdf. Acesso em: 12.nov.2012.

WAMPLER, B. 2004. Expanding Accountability Through Participatory Institutions: mayors, Citizens, and Budgeting in Three Brazilian Municipalities. Latin American Politics \& Society, Oxford, v. 46, n. 2, p. 73-99, Summer.
WARREN, M. 2002. What Can Democratic Participation Mean Today? Political Theory, Thousand Oaks, v. 30, n. 5, p. 677-701, Oct.

YOUNG, I. M. 2001. Comunicação e o Outro: além da democracia deliberativa. In: SOUZA, J. (org.). Democracia hoje: novos desafios para a teoria democrática. Brasília: UNB.

\section{OUTRASFONTES}

BELO HORIZONTE. 2007. Manual metodológico da URB-AL: instrumentos de articulação entre Planejamento Territorial e Orçamento Participativo. Belo Horizonte: Prefeitura Municipal de Belo Horizonte.

2011. Orçamento participativo 2011/2012: metodologia e diretrizes. Belo Horizonte: Prefeitura Municipal de Belo Horizonte.

BRASIL. 1988. Constituição da República Federativa do Brasil. Brasília: Senado Federal. 2000. Lei complementar n. 101, 4.maio.

BRASIL. DATASUS. 2011. Informações de Saúde - demográficas e socioeconômicas. Disponível em: http://www2.datasus.gov.br/DATASUS/ index.php? area $=0206 \& \mathrm{VObj}=\mathrm{http}: / /$ tabnet.datasus.gov.br/cgi/deftohtm.exe?ibge/ cnv/pop. Acesso em 11 nov. 2011.

CIDADE. 2003. Quem é o público do orçamento participativo - 2002. Porto Alegre: Centro de Assessoria e Estudos Urbanos.
CURITIBA. 2009. Orçamento para 2010 prevê R\$ 328 Milhões em investimentos. Agência de Notícias da Prefeitura de Curitiba, 14.set.

2011. 5 mil pessoas apresentam sugestões ao orçamento. Agência de Notícias da Prefeitura de Curitiba, 22.jul. Disponível em: http://200.140.228.6/noticias/5-mil-pessoasapresentam-sugestoes-ao-orcamento/23646. Acesso em 12.nov.2012.

PORTO ALEGRE. 2010. Orçamento participativo 2010-2011. Porto Alegre: Prefeitura Municipal de Porto Alegre.

RECIFE. 2011. Orçamento Participativo. Recife: Prefeitura Municipal de Recife.

SOS CORPO. 2008. Mulheres e orçamento participativo: fortalecendo a participação. Recife: Instituto Feminista para a Democracia. 
This document was created with Win2PDF available at http://www.win2pdf.com. The unregistered version of Win2PDF is for evaluation or non-commercial use only. This page will not be added after purchasing Win2PDF. 